TERMINUS

t. 21 (2019), z. 1 (50), s. 67-104

doi:10.4467/20843844TE.19.003.10503

www.ejournals.eu/Terminus

http://orcid.org/0000-0002-2767-0077

Justyna Zaborowska-Musiat

Uniwersytet im. Adama Mickiewicza w Poznaniu

j.zabor@amu.edu.pl

\title{
Mowa kardynała Stanisława Hozjusza ku czci zmarłego Zygmunta II Augusta, króla Polski
}

\begin{abstract}
The Speech of Cardinal Stanisław Hozjusz in Memory of the Late Sigismund II Augustus, King of Poland
\end{abstract}

The paper contains a translation of a Latin mourning speech, namely a panegyric sermon arranged in Rome by Cardinal Stanisław Hozjusz in honour of King Sigismund II Augustus, the last Polish king of the Jagiellonian dynasty, who died on 7 July 1572. It is one of a few speeches preserved to this day from the abundant oratorio-predicatory output of this Catholic theologian and polemicist, then wellknown in Europe. It was delivered by Stanisław Reszka, the secretary and close collaborator of Hozjusz, on 10 November 1572 at the church of San Lorenzo il Damaso during a solemn funeral service administered by Pope Gregory XIII. The ceremony took place in a magnificent scenery created by an elaborate castrum doloris erected especially for this ceremony by Cardinal Alessandro Farnese, the protector of Polish affairs, with the participation of Hozjusz and his close collaborators. The translation is accompanied by explanations that concern events and historical figures, geographical names, quotations, and phrases taken from the Bible and ancient authors. It is preceded by a short introduction in which, apart from the origins and circumstances of the delivery of the speech, its composition and style are discussed. The sermon has a clear structure. It consists of three parts, typical of this type of public utterance. In accordance with the customs of the epoch and the preaching textbooks of that time, the initial part (lamentatio) and the final part (consolatio) are rich in biblical phrases (especially from the prophetic books) that perfectly emphasize the 
dramatic character of the situation, as well as the significance and further consequences for Poland of the death of the last Jagiellon. The leitmotif that integrates the whole speech is a thought from Prophet Jeremiah (Jer 13:18): "your beautiful crown has come down from your head." The middle part (laudatio) is filled with the praise of Sigismund II Augustus and the Jagiellonian dynasty. Hozjusz draws here an image of the ideal ruler, enriched with Renaissance elements, such as striving for peace and good relations with neighbours, supporting humanists, excellent and refined customs, as well as a perfect mastery of the art of elocution. Following the postulates formulated by the author himself, the style of this sermon is characterized by simplicity, naturalness, and elegance.

Keywords: Warmian Cardinal Stanisław Hozjusz, Sigismund II Augustus, funeral speech, panegyric sermon

7 lipca 1572 roku w Knyszynie - jak w kilkanaście lat później wspominał Łukasz Górnicki, sekretarz kancelarii królewskiej i opiekun monarszej biblioteki - król Zygmunt II August „Naświętszy Sakrament po spowiedzi [...] przyjąwszy, rozdzielił się z tym światem, z niewymownym żalem nas wszystkich sług jego, którzy nie panaśmy mieli, ale dobrotliwego ojca"1. W ostatnich chwilach życia towarzyszyli królowi biskup krakowski Franciszek Krasiński, marszałek nadworny litewski Michał Krzysztof Radziwiłł oraz referendarz koronny Stanisław Sędziwój Czarnkowski, który czytał konającemu Pismo Święte ${ }^{2}$. Stanisław Hozjusz, który karierę rozpoczynał jeszcze za panowania Zygmunta Starego, ale ostatniemu z Jagiellonów zawdzięczał godność biskupa najpierw chełmińskiego (1548), a potem warmińskiego (1551), przebywał wówczas w Rzymie (od listopada 1569 r.). Monarcha wysłał go tam jako swojego legata w celu zintensyfikowania i zwiększenia efektywności działań w kwestii odzyskania spadku po królowej Bonie ${ }^{3}$.

${ }^{1}$ Ł. Górnicki, Dzieje w Koronie Polskiej, oprac. H. Barycz, Wrocław 2003, s. 172.

2 S. Cynarski, Zygmunt August, Wrocław 2004, s. 262.

3 Taki był oficjalny powód tej misji. Nieoficjalnie zaś król wykorzystał tę sprawę jako pretekst do oddalenia Hozjusza, który permanentnie zadręczał go napomnie- 
Wiadomość o niespodziewanej śmierci Zygmunta Augusta dotarła do Hozjusza 28 lipca 1572 roku$^{4}$. Wkrótce napłynęły do niego kondolencje od wielu dostojników Kościoła, między innymi od kardynałów Jacoba Sabella, Antonia Caraffy i Alessandra Farnese, protektora spraw polskich w Rzymie ${ }^{5}$. On sam zaś w pierwszej kolejności skierował 30 lipca list do senatu polskiego, w którym łączył się w bólu z jego członkami i jednocześnie wzywał ich do skonsolidowania wysiłków w celu zachowania w państwie jedności, zwłaszcza religijnej. $j^{6}$ Następnie, w liście z 20 sierpnia napisanym w Subiaco do papieża Grzegorza XIII Hozjusz dziękował mu za życzliwość wobec Polski i prosił w imieniu całego kraju o zarządzenie uroczystego nabożeństwa żałobnego za zmarłego króla:

Ja prawie do tego dnia nawet najmniejszego znaku zapowiadającego śmierć Najjaśniejszego Króla z ojczyzny mojej nie miałem, przeto łatwo można się domyślić, jakie w niej teraz panuje poruszenie, jakimi niepokojami i burzami jest wstrząsana. Pokornie zatem proszę Waszą Świątobliwość w imieniu całej ojczyzny mojej, w której teraz wszyscy udręczeni są wieloma różny-

niami z powodu nadmiernego - zdaniem biskupa - pobłażania innowiercom oraz wezwaniami do pogodzenia się z królową Katarzyną i porzucenia myśli o rozwodzie. Sam kardynał, znużony i zniechęcony małą skutecznością walki z protestantami we własnej diecezji, mimo dość zaawansowanego już wieku (liczył 65 lat) przyjął powierzone mu zadanie. Zob. A. Szorc, Stuga Boży Stanisław Hozjusz, w: Polscy święci, [red. J.R. Bar], t. 12, Warszawa 1987, s. 73-74.

${ }^{4}$ Informuje o tym sekretarz Hozjusza, Stanisław Reszka, w liście do Marcina Kromera napisanym w Subiaco 1 sierpnia 1572 roku. Donosi, że domownik papieża przyniósł list do Hozjusza od kardynała Como, Gallusa Ptolemeusa, zawierający tę straszną wiadomość. Z kolei 29 lipca Hozjusz otrzymał list od przebywającego w Wiedniu polskiego dyplomaty, Łukasza Podoskiego, który ją potwierdzał. Zob. $Z$ dworu Stanisława Hozjusza. Listy Stanisława Reszki do Marcina Kromera 15681582, wstęp, przeł. i koment. J.A. Kalinowska, Olsztyn 1982, s. 125.

${ }^{5}$ Zob. zestawienie ważnych dla Hozjusza wydarzeń i spraw, na których temat zabiera głos w swojej korespondencji: J. Wojtkowski, Kalendarium Stanisława Hozjusza, „Studia Warmińskie” 16 (1979), s. 95; zob. także S. Hosius, Opera omnia, t. II, Köln: Maternus Cholinus, 1584, s. 329-330 (ep. CLXX, CLXXII, CLXXIII).

${ }^{6}$ J. Wojtkowski, Kalendarium..., s. 95; S. Hosius, Opera omnia, s. 327-328 (ep. CLXIX). 
mi bardzo poważnymi troskami, skoro pewne jest, że Najjaśniejszy Król odszedł z tego życia w katolickiej wierze, przyjąwszy zgodnie z obrzędami Kościoła wszystkie sakramenty, aby Wasza Świątobliwość zarządził uroczyste egzekwie, jak zwykł zawsze czynić i w ten sposób dopełnił powziętej względem mojej ojczyzny życzliwości [przeł. J.Z.-M.]

Uroczystość odbyła się 10 listopada 1572 roku $^{8}$ w kościele pod wezwaniem św. Wawrzyńca in Damaso, który stanowił część obiektów zajmowanych przez papieską kancelarię. Rodzina Farnese wzniosła na tę okoliczność wspaniałe castrum doloris. W prace szczególnie zaangażował się kardynał Alessandro Farnese, a także polscy duchowni, zwłaszcza Hozjusz i jego sekretarz oraz bliski współ-

7 „Ego nec in hunc usque diem ex Patria mea, vel minimam quoque de morte Serenissimi Regis significationem habui, unde facile conjicere licet, qui nunc sint in ea motus, quibus fluctibus atque tempestatibus agitetur. Nunc ego supplex a S.V. peto totius Patriae meae nomine, in qua multis aliis gravissimis curis omnes distrahuntur, quando quidem illud constare dicitur, Serenissimum Regem in Catholica fide ex hac vita migrasse, omnibus Ecclesiae sacramentis rite perceptis, ut quae fieri semper consueverunt solennes exequiae, eas ipsas S.V. quoque faciendas curet, ac sic semel coeptum in Patriam meam beneficium absolvat", S. Hosius, Opera omnia, s. 331 (ep. CLXXIV).

${ }^{8}$ Taka data (dosłownie: czwartego dnia przed idami listopadowymi) widnieje w tytule mowy opublikowanej w przygotowanym przez Stanisława Reszkę, sekretarza Hozjusza, drugim tomie pism kardynała warmińskiego (S. Hosius, Opera omnia, s. 479). Juliusz A. Chrościcki bez wskazania źródeł podaje inne terminy tej uroczystości: 12 i 18 października 1572 roku oraz 12 listopada 1572 roku (a nawet 1574 r.). Zob. J.A. Chrościcki, Pompa funebris. Z dziejów kultury staropolskiej, Warszawa 1974, s. 100, 182-183, 208, 296 (Alessandro Farnese), 310 (Stanisław Reszka); idem, Architettura e docorazione dei funerali polacchi in Italia dal Cinquecento al Settcento, w: Barocco fra Italia e Polonia. Atti del IV Convegno di Studi promosso ed organizatto dal Comitato degli Studi sull'Arte dell'Accademia Polacca delle Scienze e dalla Fondazione Giorgio Cini di Venezia (Varsovia, 14-18 Ottobre 1974), a cura di J. Śląski, Warszawa 1977, s. 146-150. Oprócz uroczystego nabożeństwa uświetnionego mową Hozjusza papież - jak wynika z przywoływanego wcześniej listu Reszki zaraz po otrzymaniu wiadomości o śmierci polskiego króla nakazał odprawić egzekwie w swojej kaplicy. Podobne nabożeństwa zarządzono we wszystkich kościołach klasztornych Rzymu. Modlono się za duszę zmarłego i szczęśliwą elekcję nowego monarchy. Zob. Z dworu Stanisława Hozjusza..., s. 125. 
pracownik Stanisław Reszka ${ }^{9}$. Castrum doloris tworzyła budowla wsparta na dziesięciu kolumnach (peripteros), zwieńczona piramidą i narożnymi obeliskami z orłami. Z przodu perypteru znajdował się fryz zdobiony herbami ziem polskich oraz tablica informująca, kogo uczczono w taki sposób. Nad tablicą umieszczono rzeźby alegoryczne przedstawiające Wiarę (Fides) i Sprawiedliwość (Iustitia) - cechy, jakimi powinien charakteryzować się idealny władca. Pomiędzy nimi ustawiono rycerza na koniu, z mieczem w dłoni. Symbolizował on zarówno zmarłego króla, jak i cnotę męstwa (fortitudo). Na dole, wewnątrz tej kunsztownej konstrukcji, znajdował się sarkofag nakryty wzorzystą tkaniną, na której spoczywały symbole władzy monarszej: korona, jabłko i berło. Na ścianach nawy zawieszono szkielety z kosami. Przypominać miały o śmierci, sądzie ostatecznym i zmartwychwstaniu. Wokół budowli siedzieli zakonnicy w kapturach ze świecami w dłoniach, a wzdłuż ścian - dostojnicy Kościoła.

Hozjusz przygotował stosowne kazanie - mowę pochwalną, którą, zapewne ze względu na słaby stan zdrowia kardynała, wygłosił Stanisław Reszka ${ }^{10}$. Cechuje się ona przejrzystą, charakterystyczną dla

9 J.A. Chrościcki, Pompa funebris..., s. 183-184, 227, 296 (Alessandro Farnese), 310 (Stanisław Reszka), 100 (reprodukcja włoskiego miedziorytu rejestrującego ten obiekt i uroczystość). Według tego badacza Alessandro Farnese prawdopodobnie był autorem koncepcji tej okazjonalnej budowli, a Stanisław Reszka brał udział w przygotowaniu znajdującej się na niej inskrypcji. Tadeusz Chrzanowski (Działalność artystyczna Tomasza Tretera, Warszawa 1984, s. 72-74) wysunął hipotezę, że pomysłodawcą takiego castrum doloris był inny współpracownik i protegowany kardynała warmińskiego - rytownik, pisarz i poeta Tomasz Treter. W swoim Theatrum virtutum Stanislai Hosii (Roma 1588) zamieścił wykonaną techniką miedziorytową ilustrację przedstawiającą tę budowlę oraz jej poetycki opis. Zob. T. Treter, Rewia cnót Stanisława Hozjusza, przeł. W. Steffen, przekład przejrzał i biografią autora opatrzył T. Batóg, Poznań 2004, s. 184-187. Graficzną odbitkę tego miedziorytu znajdzie też Czytelnik na stronie internetowej Muzeum Narodowego w Warszawie (cyfrowe.mnw.art.pl, dostęp: 29.04.2019). Integralną częścią obrazu jest krótki opis informujący o okolicznościach przygotowania tego cenotafu oraz dacie uroczystych egzekwii - 10 listopada 1572 roku.

${ }_{10}$ Karol Mecherzyński (Historya wymowy w Polsce, t. 1, Kraków 1856, s. 57-58) zwraca uwagę, że Hozjusz, który bardzo poważnie traktował swoje obowiązki dusz- 
kazań pogrzebowych strukturą, jasnym, klarownym stylem, częstymi odwołaniami do Biblii, dominującymi nad aluzjami antycznymi ${ }^{11}$. Taka stylistyka wynikała w dużej mierze z religijnego charakteru uroczystości. Była także rezultatem świadomej postawy twórczej autora, jak możemy wnosić z jego listu z sierpnia 1574 roku do Andrzeja Patrycego Nideckiego, wielbiciela Cycerona, wydawcy i komentatora pism rzymskiego mówcy. Przedstawiając swoją opinię na temat przesłanego mu przez Nideckiego nieopublikowanego jeszcze Porównania Kościoła katolickiego ze zborami heretyckimi (Paralella Ecclesiae Catholicae cum haereticorum synagogis, Köln 1576), kardynał wypowiedział się również na temat właściwego stylu wypowiedzi. Postulował mowę prostą, jasną, w pełni zrozumiałą, choćby kosztem „czystości łaciny”, jaką zapewniało naśladowanie języka i stylu Cycerona. Ponadto mowa powinna być jak najbardziej naturalna, tak żeby „nie wydawało się, że jest zanadto wypracowana”"12. By osiągnąć postulowaną prostotę, przejrzystość i naturalność, a jednocześnie elegancję, należy - zdaniem Hozjusza - czerpać wzory z ksiąg biblijnych, zdobić wypowiedź myślami, wyrażeniami, odniesieniami biblijnymi, a nie wypełniać jej - kardynał przyznaje, że sam niegdyś ulegał tej

pasterskie, ułożył wiele kazań w języku łacińskim, polskim czy niemieckim i ze względu na słaby stan zdrowia ich wygłoszenie zlecał innym. Niestety, z tej dziedziny działalności biskupa warmińskiego zachowało się niewiele: kilka kazań wygłoszonych w Elblągu w 1553 roku oraz kilka mów okolicznościowych, takich jak analizowana mowa i łaciński przekład polskiej oracji, którą biskup Samuel Maciejowski wygłosił na pogrzebie Zygmunta Starego. Oba teksty ukazały się w: S. Hosius, Opera omnia, s. 462-468. Na temat spuścizny pisarskiej Hozjusza zob. K. Estreicher, Bibliografia polska, t. 18, Kraków 1901, s. 277-294; Piśmiennictwo staropolskie. Hasła osobowe A-M, red. R. Pollak (Bibliografia Literatury Polskiej „Nowy Korbut”, 2), Warszawa 1964, s. 267-269; A. Szorc, Stuga Boży..., s. 82-86.

${ }_{11}$ Taki styl wypowiedzi można dostrzec także $\mathrm{w}$ innych pismach kardynała. Tadeusz Grabowski (Piotr Skarga na tle literatury katolickiej w Polsce XVI wieku 1536-1612, Kraków 1913, s. 68-70) zwraca uwagę na doskonałe wykorzystywanie przez Hozjusza Pisma Świętego, zwięzłość, prostotę, powagę, siłę, precyzję i logikę jego wypowiedzi, a przy tym jej elegancję i wytworność pożądaną przez wielu humanistów.

${ }^{12} \mathrm{Tu}$ i niżej przekład - J.Z.-M. 
modzie - nadmiernie „kwiatkami zerwanymi ze wszystkich dzieł Cycerona”. Taka mowa jest w jego opinii jak „wazy egipskie”, do których wstawiono mnóstwo wielobarwnych, wonnych roślin ${ }^{13}$.

Początkową część mowy, tak zwaną lamentację ${ }^{14}$, zgodnie ze zwyczajami epoki, rozpoczyna Hozjusz myślą kilkakrotnie powtarzaną w kazaniu, zaczerpniętą z proroka Jeremiasza (Jr 13, 18): „Spadła korona $\mathrm{z}$ naszej głowy"15. Zdanie to dobitnie podkreślało dramatyzm całej sytuacji ${ }^{16}$. Umarł nie tylko król, jego śmierć oznaczała

13 „Gratulabor tibi, quod Aegyptiorum ollas reliqueris et ad Hebraeos eorum spoliis locupletandos animos induxeris. [...] Quo genere loquendi numquis ex probatis auctoribus usus fuerit, nescio. Sed missas faciamus ollas Aegyptiacas, quibus ego sic aliquando me fuisse memini delectatum, ut ex omnibus Ciceronis opusculis flosculos quosdam decerperem, quibus, quae scriberem, ornari putabam. Nunc eos ex Bibliis excerpere malo, nec aliam orationem esse magis elegantem iudico, quam quae Biblicorum verbis scatet plurimis. Quae vellem a te quoque non fastidiri, etiam parum esse Ciceroniana videantur. In hoc solo praecipue nobis elaborandum est, ut quoad fieri maxime poterit, perpspicue, quod sentimus, explicare queamus, nec esse dictio nostra nimis elaborata videatur. Praecipua laus orationis est perspicuitas. Etiamsi quis aberret nonnunquam a puritate Latinae dictionis, modo sic scribat, ut intelligatur, nec omnino barbariem sapiat eius oratio, non magna mihi reprehensione dignus esse videatur", S. Hosius, Opera omnia, s. 386 (ep. CCXX).

${ }^{14}$ Mowa pogrzebowa zgodnie $\mathrm{z}$ teorią Menandrosa zaadaptowaną przez autorów chrześcijańskich, zwłaszcza przez cenionego w Polsce na przełomie XVI i XVII wieku Grzegorza z Nazjanzu, powinna składać się z trzech części: lamentacji, pochwały zmarłego i jego rodziny oraz konsolacji; zob. D. Platt, Kazania pogrzebowe z przełomu XVI i XVII wieku. Z dziejów prozy staropolskiej, Wrocław 1992, s. 49-72.

${ }_{15}$ Ówczesne artes praedicandi (np. Erazma z Rotterdamu Ecclesiastes sive de ratione concionandi, 1535, czy Stanisława Sokołowskiego Partitiones Ecclesiasticae, 1589) zalecały, by orator kościelny, niezależnie od typu kazania, rozpoczynał swe wystąpienie od cytatu lub myśli z Pisma Świętego. Jak zauważa Dobrosława Platt na podstawie analizy polskich kazań pogrzebowych z przełomu XVI i XVII wieku, biblijna fraza stanowiła motto, któremu podporządkowana była dalsza część mowy. Ponadto miała ona poruszyć słuchaczy. Dlatego autorzy chętnie poszukiwali inspiracji w tekstach proroków Izajasza, Jeremiasza czy Amosa; zob. ibidem, 17-45.

${ }_{16}$ Ta krótka, a zarazem bardzo sugestywna fraza mogła także nawiązywać do ówczesnego ceremoniału obowiązującego podczas pogrzebów monarchów oraz niektórych dostojników państwowych. Ważnymi elementami tego rytuału były: konny wjazd do kościoła i spektakularny upadek archimima udającego króla, uderzanie 
także kres domu jagiellońskiego, który władał Polską od ponad stu osiemdziesięciu lat. Postawiło to szlacheckie społeczeństwo Rzeczypospolitej przed koniecznością wyboru monarchy spośród kandydatów, którzy wywodzili się nie tylko z obcych dynastii, lecz także z państw o odmiennych tradycjach rządzenia. Odbiciem tej nowej rzeczywistości były doskonale wyczuwane przez biskupa, o czym świadczy cytowany wcześniej fragment listu do papieża Grzegorza XIII, pesymistyczne nastroje społeczeństwa polskiego, powszechny niepokój i strach przed nieznaną przyszłością ${ }^{17}$. Atmosferę niepewności i trwogi potęgowała jeszcze szerząca się po całym kraju zaraza oraz ponure przepowiednie, które mocno przemawiały do wyobraźni, zwłaszcza niższych warstw społecznych. Atmosferę tę podsycała również publicystyka polityczna, pełna czarnych wizji zamętu i chaosu. Wnikliwy obserwator tamtych wydarzeń, prawnik i historyk, późniejszy sekretarz królów Stefana Batorego i Zygmunta III, Reinhold Heidenstein, odnotował, że powszechnie zawładnęła umysłami „dziwna obawa i troska o losy kraju”, tak jakby po śmierci ostatniego Jagiellona „państwo całe wraz z nim zginąć miało"18.

Rozwijając inicjalną frazę, Hozjusz zestawia ogólnie zasygnalizowane nieszczęścia, które wraz ze zgonem króla spadły na Rzeczpospolitą i jeszcze zdarzyć się mogą w niepewnej przyszłości, z największymi klęskami, jakie dotknęły lud izraelski w czasach proroka Jeremiasza. Ich kulminacją - przypomnijmy - było zburzenie Jerozolimy i niewola babilońska. Tak samo jak w przypadku Izraelitów aktu-

o ziemię przez króla-elekta i wybrane osobistości insygniami (hełmem, tarczą i mieczem) należącymi do poprzednika, łamanie pieczęci i innych oznak sprawowanej władzy. Zob. J. Chrościcki, Pompa funebris..., s. 52. Szczegółowe opisy przebiegu uroczystości pogrzebowych dwóch ostatnich Jagiellonów na polskim tronie znajdzie Czytelnik w: Z. Gloger, Encyklopedia staropolska, t. 4, Warszawa 1985, s. 55-57.

${ }_{17}$ M. Korolko, Klejnot swobodnego sumienia. Polemika wokót konfederacji warszawskiej w latach 1573-1658, Warszawa 1974, s. 41-42.

${ }_{18}$ R. Heidenstein, Dzieje Polski od śmierci Zygmunta Augusta do roku 1594. Ksiąg XII, przeł. M. Gliszczyński, życiorys W. Spasowicz, t. 1, Petersburg 1857, s. 1113, cyt. za: M. Korolko, Klejnot swobodnego sumienia..., s. 41. 
alne nieszczęścia polskie, a nawet sama niespodziewana śmierć monarchy, były - zdaniem Hozjusza - skutkiem grzechów popełnionych przez jego rodaków, grzechów, które wprowadziły rozłam pomiędzy nimi a Bogiem. Dla kardynała warmińskiego występkami tymi były oczywiście tolerowanie w państwie protestantów i kolejne ustępstwa na ich rzecz kosztem jedności religijnej, gwarantującej w jego przekonaniu jedność i trwałość państwa. Wymienić tu można uzyskane po wielu latach na sejmie 1562/1563 roku i potwierdzone w roku 1565 zniesienie egzekucji starościńskiej wyroków sądów duchownych w sprawach o wiarę i dziesięcinę oraz tak zwaną zgodę sandomierską, zawartą w 1570 roku pomiędzy protestantami ( $\mathrm{z}$ wyłączeniem braci polskich) w celu ochrony dysydentów przed większością katolicką. Porozumienie to stało się preludium do zawartej trzy lata później, już po śmierci Zygmunta Augusta, konfederacji warszawskiej, do czego Hozjusz starał się nie dopuścić, a po jej zawarciu nie ustawał w wysiłkach, by nowo wybrany król Henryk Walezy jej nie potwierdzi1 ${ }^{19}$.

Tego pesymistycznego nastroju mowy nie łagodzi nawet niezbędna w tego typu wystąpieniach ogólna refleksja (oczywiście utrzymana w duchu chrześcijańskim) na temat nieuchronności śmierci, krótkotrwałości i znikomości życia, które jest niczym innym jak tylko ulotnym epizodem, etapem wstępnym do lepszego żywota wiecznego. Hozjusz na poparcie tej refleksji przywołuje stosowne myśli z Biblii oraz z bliżej nieokreślonego „poganina”. Jest nim zapewne niezwykle ceniony w renesansie Cyceron. Kończy zaś tę wstępną partię bardzo sugestywnym obrazem parafrazującym scenę z Ewangelii według św. Łukasza 13, 27-28. Przedstawia więc zmarłego króla, który, sam już daleki od wszelkich trosk, wymownym milczeniem napomina swoich poddanych, by zamiast go opłakiwać, zapłakali nad swoimi grzechami, które stały się przyczyną - tu Hozjusz powtarza początkowy cytat, spinając nim niczym klamrą pierwszą część kazania - że „spadła korona z naszej głowy”.

${ }^{19}$ Na temat działań Hozjusza w tej sprawie zob. M. Korolko, Klejnot swobodnego sumienia..., s. 68-71. 
Część drugą mowy wypełnia pochwała Zygmunta Augusta, w której zgodnie $z$ obowiązującymi od antyku konwencjami nie mogło zabraknąć rodowej genealogii i podkreślenia zasług przodków, co zaczyna się oczywiście od założyciela dynastii i prowadzi do konkluzji, że zmarły król z pewnością dorównał swoim poprzednikom, jeśli ich nie przewyższył. Rozwijając to ogólne stwierdzenie, Hozjusz kreśli bardziej szczegółowy portret monarchy, jego zalet i cnót, który zarazem jest obrazem władcy idealnego. Wzorem renesansowych humanistów znacznie poszerza średniowieczny ideał króla-rycerza, sprawiedliwego, dobrego i hojnego „ojca ludu”, obrońcy wiary i opiekuna Kościoła, o nowe elementy ${ }^{20}$. Biskup warmiński ukazuje zatem ostatniego Jagiellona jako „niezaniedbującego żadnego obowiązku króla dzielnego i wielkiego", sprawiedliwego, roztropnego, w sprawach trudnych i ważnych zasięgającego opinii swoich doradców, zwłaszcza senatorów duchownych, ceniącego i zabiegającego o pokój i dobre relacje z sąsiadami, pobożnego i dbającego o dobro Kościoła. Ponadto podkreśla jego opiekę nad humanistami, co przyczyniło się do rozwoju tych nauk w Polsce, doskonałe, wytworne obyczaje, wspaniałą wymowę. Ta w połączeniu $\mathrm{z}$ rozwagą i roztropnością wielokrotnie budziła zdumienie i podziw gości i posłów z innych krajów przybywających na dwór Jagiellonów. Hozjusz zwraca też uwagę na łagodność usposobienia monarchy, jego życzliwość i uprzejmość, szacunek okazywany wszystkim, a zwłaszcza senatorom duchownym, brak pychy uwidaczniający się także w prostocie stroju. Cechą charakterystyczną dla tej partii tekstu, przejawem postulowanej przez Hozjusza prostoty, jest całkowita rezygnacja z typowego dla renesansowych wystąpień panegirycznych (np. mów Orzechowskiego i Kromera ułożonych na okoliczność pogrzebu Zygmunta Starego) zestawiania cnót i osiągnięć chwalonego władcy z dokonaniami wybitnych osobistości grecko-rzymskiego antyku.

${ }^{20}$ Zob. H. Dziechcińska, Wzory osobowe, w: Słownik literatury staropolskiej. Średniowiecze. Renesans. Barok, red. T. Michałowska, przy udziale B. Otwinowskiej, E. Sarnowskiej-Temeriusz, wyd. 2 popr. i uzup., Wrocław 1998, s. 1063. 
W prezentacji tak wyidealizowanego wizerunku ostatniego Jagiellona na polskim tronie Hozjusz należy do stosunkowo wąskiego grona ludzi, związanych przede wszystkim z kancelarią królewską (np. Marcin Kromer, Stanisław Karnkowski, Łukasz Górnicki), zdecydowanie pozytywnie oceniających jego panowanie. Jak zauważa Juliusz Nowak-Dłużewski, „zabrakło [...] Zygmuntowi Augustowi chwalców po jego śmierci, choć miał ich sporo za życia"²1, co po części wytłumaczyć można tym, że w zamieszaniu politycznym nie zadbano o zamówienie stosownej literatury funeralnej u odpowiednich autorów. Dość często natomiast pojawiały się wówczas teksty, w których krytykowano przede wszystkim jego niezdecydowanie, kunktatorstwo, przeciąganie obrad sejmowych, odkładanie ważnych decyzji do jutra, wreszcie królewskie amory i rządy kobiece na dworze ${ }^{22}$.

Podsumowując część laudacyjną, Hozjusz przypomina ostatnie chwile życia króla Zygmunta Augusta, który opatrzony sakramentami powierzył swoją duszę Bogu i odszedł w spokoju. Następnie powraca do początkowej myśli proroka Jeremiasza, by jeszcze raz podkreślić wielką stratę dla Polski, jaką była śmierć tego monarchy, a wraz z nią kres całego domu jagiellońskiego. Ponowne powtórzenie tej myśli ponadto sygnalizuje trzecią część kazania - pocieszenie (consolatio). Ta najkrótsza partia mowy także obfituje w odwołania biblijne. I również jest bardzo dramatyczna. Tutaj jednak początkowy pesymizm ustępuje miejsca pokornej rezygnacji i całkowitemu zaufaniu Bogu. Słowami zaczerpniętymi z Lamentacji Jeremiasza $(5,19-22)$ Hozjusz nawołuje do żalu za grzechy, ukorzenia się i zawierzenia Stwórcy. Ten finalny, podniosły apel, złożony z błagalnych zapytań skierowanych wprost do Najwyższego i pokornych deklaracji gotowości powrotu na właściwą drogę, płynnie przechodzi we w pełni autorską modlitewną prośbę o nowego króla podobnego do ostatnich Jagiellonów, która zamyka konsolację i całe kazanie.

${ }^{21}$ J. Nowak-Dłużewski, Okolicznościowa poezja polityczna w Polsce. Pierwsi królowie elekcyjni, Warszawa 1969, s. 10.

22 Ibidem, s. 7-12; zob. też S. Cynarski, Zygmunt August, s. 210-214. 
Podstawę przekładu tej jednej z nielicznych do dzisiaj zachowanych pozycji z dorobku oratorsko-kaznodziejskiego Stanisława Hozjusza, znanego w całej Europie teologa i polemisty katolickiego, stanowi tekst opublikowany w tomie drugim zbiorowego wydania dzieł kardynała Opera omnia (Köln: Maternus Cholinus, 1584). W przypisach biograficznych bez podania adresu bibliograficznego wykorzystano stosowne informacje z: Pocztu władców Polski autorstwa Marka Ferenca [et. al.] (wstęp J. Wyrozumski, Ożarów Mazowiecki 2015), Pocztu królów i książąt polskich pod redakcją Andrzeja Garlickiego (wyd. 8, Warszawa 1998), Polskiego słownika biograficznego wydawanego od 1935 roku przez PAU i PAN, Encyklopedii katolickiej pod redakcją Feliksa Gryglewicza, Romualda Łukaszyka i Zygmunta Sułowskiego (Lublin 1973-2014) oraz z pracy Stanisława Cynarskiego Zygmunt August (Wrocław 2004).

\section{Bibliografia}

\section{Źródła drukowane}

Górnicki Ł., Dzieje w Koronie Polskiej, oprac. H. Barycz, Wrocław 2003.

Heidenstein R., Dzieje Polski od śmierci Zygmunta Augusta do roku 1594. Ksiag XII, przeł. M. Gliszczyński, życiorys W. Spasowicz, t. 1, Petersburg 1857.

Hosius S., Opera omnia, t. II, Köln: Maternus Cholinus, 1584.

Treter T., Rewia cnót Stanisława Hozjusza, przeł. W. Steffen, przekład przejrzał i biografią autora opatrzył T. Batóg, Poznań 2004.

$Z$ dworu Stanisława Hozjusza. Listy Stanisława Reszki do Marcina Kromera 15681582, wstęp, przeł. i koment. J.A. Kalinowska, Olsztyn 1982.

\section{Opracowania}

Chrościcki J.A., Architettura e docorazione dei funerali polacchi in Italia dal Cinquecento al. Settcento, w: Barocco fra Italia e Polonia. Atti del IV Convegno di Studi promosso ed organizatto dal Comitato degli Studi sull'Arte dell'Accademia Polacca delle Scienze e dalla Fondazione Giorgio Cini di Venezia (Varsovia, 14-18 ottobre 1974), a cura di J. Śląski, Warszawa 1977, s. 143-153.

Chrościcki J.A., Pompa funebris. Z dziejów kultury staropolskiej, Warszawa 1974. 
Chrzanowski T., Działalność artystyczna Tomasza Tretera, Warszawa 1984.

Cynarski S., Zygmunt August, Wrocław 2004.

Dziechcińska H., Wzory osobowe, w: Słownik literatury staropolskiej. Średniowiecze. Renesans. Barok, red. T. Michałowska, przy udziale B. Otwinowskiej, E. Sarnowskiej-Temeriusz, wyd. 2 popr. i uzup., Wrocław 1998.

Encyklopedia katolicka, red. F. Gryglewicz, R. Łukaszyk, Z. Sułowski, Lublin 19732014.

Estreicher K., Bibliografia polska, t. 18, Kraków 1901.

Ferenc M. [et. al.], Poczet władców Polski, wstęp J. Wyrozumski, Ożarów Mazowiecki 2015.

Gloger Z., Encyklopedia staropolska, t. 4, Warszawa 1985.

Grabowski T., Piotr Skarga na tle literatury katolickiej w Polsce XVI wieku 15361612, Kraków 1913.

Korolko M., Klejnot swobodnego sumienia. Polemika wokół konfederacji warszawskiej w latach 1573-1658, Warszawa 1974.

Mecherzyński K., Historya wymowy w Polsce, t. 1, Kraków 1856.

Nowak-Dłużewski J., Okolicznościowa poezja polityczna w Polsce. Pierwsi królowie elekcyjni, Warszawa 1969.

Piśmiennictwo staropolskie. Hasła osobowe A-M, red. R. Pollak (Bibliografia Literatury Polskiej „Nowy Korbut”, 2), Warszawa 1964.

Platt D., Kazania pogrzebowe z przełomu XVI i XVII wieku. Z dziejów prozy staropolskiej, Wrocław 1992.

Poczet królów i książąt polskich, red. A. Garlicki, wyd. 8, Warszawa 1998.

Polski słownik biograficzny, Kraków 1935-.

Szorc A., Sługa Boży Stanisław Hozjusz, w: Polscy święci, [red. J.R. Bar], t. 12, Warszawa 1987

Wojtkowski J., Kalendarium Stanisława Hozjusza, „Studia Warmińskie” 16 (1979). 


\title{
Mowa Stanisława Hozjusza wygłoszona przez Stanisława Reszkę $e^{23}$ podczas nabożeństwa żałobnego za Zygmunta II Augusta, króla Polski, uroczyście sprawowanego w kościele św. Wawrzyńca w domu Damazego w Rzymie ${ }^{24} 10$ listopada 1572 roku
}

\begin{abstract}
Gdy przepełniony Duchem Świętym prorok Jeremiasz ${ }^{25}$ klęski ludu izraelskiego zapowiadał, pośród innych wymieniał i to: „Spadła ko-
\end{abstract}

${ }^{23}$ Ks. Stanisław Reszka (1544-1600) - sekretarz i pierwszy biograf Stanisława Hozjusza, z którym związany był od roku 1559 aż do śmierci kardynała (1579). Był jego najbliższym współpracownikiem. Redagował łacińskie listy Hozjusza, kopiował jego dzieła, kardynał miał bowiem zwyczaj przed publikacją oddawać je do recenzji. Po śmierci Hozjusza przygotował do druku drugi tom edycji zbiorowej jego pism, obejmujący także dotąd niepublikowane teksty (S. Hosius, Opera omnia, Köln: Maternus Cholinus, 1584). Na temat tej oraz innych edycji dzieł Hozjusza zob. K. Estreicher, Bibliografia polska, t. 18, Kraków 1901, s. 277-293. Reszka wypełniał także różne zadania dyplomatyczne, zlecone przez swojego mocodawcę. Posłował między innymi do Francji po elekcji Henryka Walezego na króla Polski, by nie dopuścić do zaprzysiężenia konfederacji warszawskiej.

${ }^{24}$ Kościół św. Wawrzyńca w domu Damazego - pierwotnie była to bazylika pod wezwaniem św. Wawrzyńca, rzymskiego diakona, który poniósł męczeńską śmierć w 258 roku w czasie prześladowań zainicjowanych przez cesarza Waleriana. Bazylikę ufundował papież Damazy około 370 roku na parceli, na której według legendy znajdował się dom rodzinny męczennika. W XVI wieku świątynia ta została przebudowana i włączona do renesansowego pałacu wzniesionego w latach 1489-1513 przez kardynała Rafaela Riario, odebranego mu później przez papieża Leona X za udział w spisku przeciwko niemu. W pałacu urządzono kancelarię papieską (Palazzo della Cancelleria).

${ }^{25}$ Jeremiasz (ok. 650 - po 586 r. p.n.e.) - jeden $\mathrm{z}$ tak zwanych większych proroków biblijnych. Działał w Jerozolimie w najtragiczniejszych dla królestwa Judy czasach. W 597 roku p.n.e. Nabuchodonozor zdobył Jerozolimę, zburzył świątynię oraz deportował aktywnych politycznie Judejczyków. Wydarzenia te rozpoczęły tak zwaną niewolę babilońską, która zakończyła się około 536 roku p.n.e., kiedy to Cyrus Starszy zezwolił Żydom powrócić do kraju. W pełnych dramatyzmu mowach, spisanych najprawdopodobniej przez sekretarza Jeremiasza, Barucha, prorok prze- 
rona $\mathrm{z}$ naszej głowy"26. Wolę jednak przemilczeć nieszczęścia, jakie z tego wynikają, by nie wzbudzić jeszcze większego żalu w sercach naszych, wystarczająco już zresztą bólem przejętych. Cóż to? Czyż słów proroka nie można odnieść do nas? Wszakże to z powodu naszych grzechów, którymi wielki gniew Boży wzbudziliśmy, osieroceni zostaliśmy przez króla, którego raczej ojcowskiej dobroci zawsze doświadczaliśmy niż władzy królewskiej w ciągu czterdziestu dwóch lat, gdy stał on u steru państwa, przez pewien czas razem z ojcem, a potem sam ${ }^{27}$. Spadła zaiste korona $\mathrm{z}$ naszej głowy, jednak nie dla tego, dla którego to nabożeństwo sprawujemy, lecz dla nas. Albowiem co do niego, to ufni w miłosierdzie Boże bądźmy przekonani, że nasz król nie tylko nie umarł, lecz także powstał i wstąpił do nieba. I zaprawdę nie stracił korony, lecz zamienił ją na inną, wspanialszą. Jakaż może być bowiem na tym świecie inna korona chwały niż ta, o której czytamy u proroka? „Wszelkie ciało to jakby trawa, a cały wdzięk jego jest niby kwiat polny. Trawa usycha, więdnie kwiat.

widywał upadek państwa i niewolę. Upatrywał w tym karę Boską za niewierność i nieprzestrzeganie Bożych nakazów. Zob. Wstęp do Starego Testamentu, red. ks. L. Stachowiak, Poznań 1990, s. 282-285.

${ }^{26}$ Hozjusz nawiązuje do Jr 13,17-18: „A jeżeli tego nie posłuchacie, będę potajemnie płakał nad waszą pychą. Będę płakał nieustannie i zamienią się w potoki łez moje oczy, bo trzoda Pańska idzie w niewolę. Powiedz do króla i królowej: «Usiądźcie zupełnie nisko, albowiem spadła z waszych głów korona chwały»". Modyfikuje jednak zacytowane w mowie ostatnie zdanie tego fragmentu w celu powiązania go z aktualną sytuacją w Rzeczypospolitej. Dla utrzymania współczesnego charakteru przekładu wszystkie zacytowane w samym kazaniu oraz przypisach fragmenty pochodzą z edycji: Pismo Święte Starego i Nowego Testamentu w przekładzie z języków oryginalnych, oprac. zespół biblistów polskich z inicjatywy benedyktynów tynieckich, wyd. 3 popr., Poznań 1980 . W przypadku rozbieżności podaję też stosowny fragment z: Biblia w przekładzie ks. Jakuba Wujka z 1599 r., transkrypcja typu „B” oryginalnego tekstu z XVI w. i wstępy ks. J. Frankowski, Warszawa 1998.

274 grudnia 1529 roku Zygmunt August został uznany jednomyślnie przez radę litewską wielkim księciem. Na króla Polski został koronowany za życia swego ojca, 20 lutego 1530 roku. Samodzielne rządy sprawował od 1 kwietnia 1548 roku. 
Prawdziwie trawą jest naród"28, prawdziwie trawą jest król i każda inna, choćby najwyższa władza. „Dzisiaj królem - mówi Mędrzec jutro umiera"29. Trawa usycha, więdnie kwiat. Mamy przeto nadzieję, że król tę doczesną koronę, przemijającą niczym kwiat, zamienił na inną, nieprzemijającą i niezniszczalną, trwającą w Bożym miłosierdziu. I jeśli ktoś na niego spojrzy, [zrozumie], że wiedzie mu się o wiele szczęśliwiej niż nam, ponieważ powołany został do siedziby błogosławionych. Tam cieszy się wiekuistą chwałą, podczas gdy my, żyjąc na tym łez padole ${ }^{30}$, nie czynimy nic innego prócz tego, że umieramy nie tylko każdego dnia, ale w każdej chwili. Porównując więc nasze życie z życiem błogosławionych dusz, należałoby - zauważył to już pewien poganin - nazwać je śmiercią [raczej] niż życiem $^{31}$. Król zatem wzniósł się już do nieba, gdzie nie umrze [nigdy]

${ }^{28}$ Iz 40,6-8: Wszelkie ciało to jakby trawa, a cały wdzięk jego jest niby kwiat polny. Trawa usycha, więdnie kwiat, gdy na nie wiatr Pana powieje. <Prawdziwie trawą jest naród $>$. Trawa usycha, więdnie kwiat, lecz słowo Boga naszego trwa na wieki”. Jakub Wujek przetłumaczył ten fragment następująco: „Wszelkie ciało to jakby trawa, a wszelka chwała jego jak kwiat polny. Uschła trawa i opadł kwiat, bo duch Pański wionął nań. (Prawdziwie lud jest trawa). Uschła trawa i opadł kwiat, lecz słowo Pana naszego trwa na wieki”. Myśl tę wielokrotnie odnajdujemy także w Księdze Psalmów, na przykład w Psalmie 103(102),15-16: „Dni człowieka są jak trawa; kwitnie jak kwiat na polu: ledwie muśnie go wiatr, a już go nie ma”.

29 Syr 10,10-11: „[...] dzisiaj królem - jutro umiera. Gdy człowiek życie zakończy, odziedziczy zgniliznę, bestie, robaki”. W przekładzie Wujka z kolei czytamy: „W szystkich mocarzów krótki żywot [...] tak i król dziś jest, a jutro umrze. Bo kiedy człowiek umrze, odziedziczy węże i bestie, i robaki” (Syr 10,11-13).

${ }^{30}$ Padół płaczu (dolina łez) - niezidentyfikowana dolina wspomniana w Psalmie 84(83),7; w sensie przenośnym oznacza ziemię jako miejsce ludzkich cierpień oraz życie doczesne.

${ }^{31}$ Hozjusz może tu nawiązywać do cenionego przez renesansowych humanistów Cycerona. W Rozmowach tuskulańskich I 31, 75 czytamy: „obecne życie nasze jest śmiercią („nam haec quidem vita mors est”), Cyceron, Rozmowy tuskulańskie; w: idem, Rozmowy tuskulańskie i inne pisma, przeł. J. Śmigaj, Z. Cierniakowa, W. Kornatowski, Warszawa 2010, s. 42; tekst łaciński podaję za: M.T. Cicero, Tusculanae disputationes, rec. M. Pohlenz, Stutgardiae 1965, s. 256. Z kolei w Państwie VI, 14 filozof mówi: „Żywi są bowiem tylko ludzie uwolnieni z okowów ciała przypominającego więzienie. Śmiercią jest ów stan zwany przez was życiem” („immo vero 
więcej i gdzie - jak mamy nadzieję - śmierć nie będzie miała nad nim władzy tak, że to jego odejście, które powinniśmy przyjąć raczej z radością niż ze łzami, okazuje się - jak oczekujemy - wstąpieniem do nieba.

Stamtąd zaś przemawia do nas bezgłośnie tymi słowy: Dzieci moje, które otaczałem ojcowską życzliwością i o których dobro zawsze się troszczyłem nie inaczej, jak rodzic troszczy się o dzieci, nie płaczcie nade mną, lecz nad sobą i waszymi grzechami ${ }^{32}$, które sprowadziły niezgodę pomiędzy wami i waszym Bogiem. To $\mathrm{z}$ ich powodu nie dla mnie, jako że cieszę się teraz wiekuistą chwałą, lecz dla was spadła korona $z$ naszej głowy. Na temat tej więc głowy, z której spadła korona, mowę tę podjęto. Nie oczekujcie jednak, że powiemy wszyst-

[...] hi vivunt qui e corporum vinclis tamquam e carcere evolaverunt, vestra quae dicitur vita mors est"), M.T. Cyceron, O państwie, w: idem, O państwie, O prawach, przeł. I. Żółtowska, Kęty 2016, s. 89; cytat łaciński za: M.T. Cicero, De re publica, rec. K. Ziegler, Lipsiae 1969, s. 129. Refleksje na temat znikomości i krótkości ludzkiego życia wielokrotnie pojawiają się też u Seneki. W Pocieszeniu do Polibiusza XI 2 czytamy: „Jaka to zresztą nowina, że umiera człowiek, którego całe życie nie jest niczym innym niż wędrówką do śmierci” („quid est enim novi hominem mori, cuius tota vita nihil aliud quam ad mortem iter est"), L.A. Seneka, Pocieszenie do Polibiusza, w: idem, Dialogi, przeł., wstęp i koment. L. Joachimowicz, Warszawa 1998, s. 464; tekst łaciński za: L.A. Seneca, Opera, rec. F. Haase, vol. 1, Lipsiae 1852, s. 228. Myśl tę Seneka rozwija w Listach moralnych do Lucyliusza III 24: „śmierć nie spotyka nas nagle, lecz robi postępy powoli, że umieramy po troszeczku co dzień. Co dzień uchodzi jakaś cząstka życia i nawet wtedy, gdy rośniemy, życie się skraca. Oto przebyliśmy dzieciństwo, a potem lata młodzieńcze. Ile czasu minęło po dzień wczorajszy, to już przepadło, a i ten dzień, który właśnie spędzamy, również dzielimy ze śmiercią" („non repente nos in mortem incidere sed minuatim procedere. Cotidie morimur; cotidie enim demittitur aliqua pars vitae, et tunc quoque cum crescimus vita decrescit. Infantiam amisimus, deinde pueritiam, deinde adulescentiam. Usque ad hesternum quidquid transit temporis perit; hunc ipsum quem agimus diem cum morte dividimus"), L.A. Seneka, Listy moralne do Lucyliusza, przeł. W. Kornatowski, Warszawa 1998, s. 116; tekst łaciński za: L.A. Seneca, Ad Lucilium Epistulae morales, rec. L.D. Reynolds, Oxonii 1965, t. 1, s. 70-71.

${ }^{32}$ Parafraza słów z Łk 23,27-28: „I szła za nimi wielka rzesza ludu i niewiast, które płakały i użalały się nad nim. Jezus zaś obróciwszy się do nich, rzekł: Córki Jerozolimskie! Nie płaczcie nade mną, ale same nad sobą płaczcie i nad dziećmi waszymi”. 
ko ze szczegółami, co można by powiedzieć. Do tego nie starczyłoby dnia. Wiele spraw dotkniemy raczej pobieżnie, by przedstawić dokładniej - jeśli starczy zdolności - czyny i wspaniałe cnoty naszego króla. Nie możemy [tutaj] jednak nie wyjaśnić samego początku, jak do tego wszystkiego doszło.

Mija już prawie dwieście lat, odkąd królem naszego państwa ${ }^{33}$ został wielki książę litewski Jagiełło ${ }^{34}$, słynny wieloma czynami wojennymi. Wprawdzie nie był wtajemniczony $\mathrm{w}$ misteria wiary chrześcijańskiej, jednak gdy poprosił, by dano mu za żonę Jadwigę ${ }^{35}$, córkę Ludwika Węgierskiego ${ }^{36}$, króla Polski, która była już korono-

${ }^{33}$ Dosł.: „koroną na naszej głowie zaczął być wielki książę litewski Jagiełło”. Hozjusz na początku drugiej części kazania (tzw. laudatio) celowo nawiązuje do inicjującego całą mowę cytatu z proroka Jeremiasza.

${ }^{34}$ Władysław II Jagiełło (ok. 1351-1434) - syn wielkiego księcia litewskiego Olgierda i Julianny Twerskiej; od 1377 roku wielki książę litewski, w 1386 roku został mężem Jadwigi Andegaweńskiej i królem Polski. Po jej śmierci (1399) zawarł jeszcze trzy małżeństwa. Z ostatniego związku z Sonką (Zofią) Holszańską, córką kniazia Andrzeja Holszańskiego i Aleksandry Druckiej, Jagiełło miał trzech synów: Władysława (1424-1444), Kazimierza, zmarłego we wczesnym dzieciństwie (1426-1427), i Kazimierza, przyszłego króla Polski (1427-1492). Panowanie Władysława II Jagiełły upłynęło pod znakiem walk z zakonem krzyżackim. Król zacieśnił także związki Polski i Litwy (unia w Horodle w 1413 r. i w Grodnie w 1432 r.).

${ }^{35}$ Jadwiga (ok. 1374-1399) - córka Ludwika I Wielkiego (Węgierskiego) i Elżbiety Bośniaczki. Po śmierci Kazimierza Wielkiego, który nie pozostawił męskiego potomka, zasiadła na tronie polskim (koronacja 16 października 1384 r.). Na mocy umowy w Krewie w 1386 roku poślubiła Władysława Jagiełłę. Zmarła w połogu, także wkrótce po narodzinach zmarła jej córka Elżbieta Bonifacja. Królowa dzięki swej religijności i rozlicznym miłosiernym uczynkom zyskała wielką miłość poddanych. Była wykształcona. Miała dość bogatą bibliotekę, uzupełnianą o wciąż nowe dzieła, często tłumaczone na jej polecenie na język polski (np. żywoty świętych, pisma ojców Kościoła, fragmenty Pisma Świętego). Z imieniem Jadwigi łączy się powstanie Psałterza floriańskiego. Skupiła wokół siebie grono wybitnych intelektualistów, duchownych i polityków. W testamencie poleciła Jagielle odnowienie Akademii Krakowskiej, przeznaczając na ten cel swe szaty i kosztowności, co też monarcha wypełnił w 1400 roku.

${ }^{36}$ Ludwik I Wielki (1326-1382) - syn Karola Roberta z dynastii Andegawenów i Elżbiety Łokietkówny, od 1342 roku król Węgier, a od 1370 - po bezpotomnej śmierci Kazimierza Wielkiego - także Polski. Na Węgrzech przeprowadził wiele re- 
waną królową, przyrzekł, że połączy Litwę z Królestwem Polskim i że przyjmie wiarę chrześcijańską ${ }^{37}$. [Przyrzekł też], że dołoży starań, by to samo uczyniła cała Litwa i Żmudź, rozległe ziemie, nad którymi panował. Zgodnie z tą umową wypełnił swoje przyrzeczenia, zwłaszcza że w tej sprawie nie pożądano niczego prócz rozkrzewienia wiary chrześcijańskiej oraz by ludy, które powodowane wojowniczym duchem toczyły pomiędzy sobą krwawe wojny, przyjąwszy jedno ciało Chrystusa, rywalizowały we wzajemnej życzliwości i miłości jak wcześniej w nienawiści, tak żeby w tym względzie jedna strona nie ustępowała drugiej, lecz żeby niczym członki jednego ciała z Jego powodu obdarzyły się wzajemną miłością. I rzeczywiście, ta rzecz szła pomyślnie. Albowiem skoro tylko został koronowany, natychmiast wraz z żoną, arcybiskupem gnieźnieńskim oraz z wieloma kapłanami wyruszył na Litwę, [gdzie] zgasił święty ogień czczony przez barbarzyński lud, zniszczył świątynie i ołtarze, przy których czczono bałwany, i zatroszczył się o wpojenie prawd chrześcijańskich jak naj-

form, które przyczyniły się do rozkwitu państwa. Inaczej rzecz miała się w Polsce. Król bywał tu rzadko, pozostawiając władzę w rękach wyznaczonych przez siebie namiestników. Główną ideą jego polityki względem Polski było zapewnienie korony jednej z trzech córek, które miał z trzeciego małżeństwa z Elżbietą Bośniaczką. Ostatecznie tron polski otrzymała najmłodsza $\mathrm{z}$ nich, Jadwiga.

${ }^{37}$ Oddanie Jagielle polskiej korony po ślubie z Jadwigą, przyjęcie chrztu przez wielkiego księcia i jego poddanych, odzyskanie przez przyszłego króla wszystkich utraconych przez Polskę terytoriów (chodziło zwłaszcza o Pomorze, Ziemię Lubuską, Śląsk, Ruś Halicką i Włodzimierską), przyłączenie na zawsze wszystkich ziem litewskich i ruskich Jagiełły do Korony - były to główne punkty umowy sukcesyjnej zawartej w Krewie 14 sierpnia 1385 roku przez panów polskich z wielkim księciem litewskim Jagiełłą, która stała się początkiem unii polsko-litewskiej. Zgodnie z warunkami tego aktu 15 lutego 1386 roku najpierw Jagiełło, a potem jego bracia po uprzednim przygotowaniu uczynili wyznanie nowej wiary i przyjęli chrzest $\mathrm{z}$ rąk arcybiskupa gnieźnieńskiego Bodzanty oraz biskupa krakowskiego Jana Radliny. Jagiełło przyjął imię Władysław po pradziadzie Jadwigi, Władysławie Łokietku, który zjednoczył Koronę Polską. Wkrótce potem odbył się ślub Jagiełły z Jadwigą (18 lutego 1386 r.) oraz koronacja (4 marca 1386 r.). Jesienią zaś monarcha wyruszył na Litwę, by wypełnić zobowiązania krewskie dotyczące chrztu jego litewskich poddanych. 
liczniejszym ${ }^{38}$. Ponieważ polscy księża nie znali wystarczająco języka Litwinów (ten nie mniej różni się od polskiego niż niemiecki od włoskiego), nie wzdragał się [głosić] Ewangelii, a nawet sam bywał tłumaczem kapłanów i troszczył się o to, co dotyczyło nauczania wiary chrześcijańskiej oraz oczyszczania przez kapłanów w wodzie chrztu od zmazy grzechów.

Spośród wielu zwycięstw szczególnie zasłynął tym, które odniósł pod Dąbrownem, gdzie w jednej bitwie pokonano i zabito pięćdziesięciu [pięćdziesiąt tysięcy?] wrogów ${ }^{39}$. W drugim zaś roku czterdzie-

${ }^{38}$ Hozjusz idzie tutaj za przekazem Długosza. W rzeczywistości, gdy Władysław II Jagiełło wyruszył na przełomie 1386 i 1387 roku z misją chrystianizacyjną na Litwę, nie wzięła $\mathrm{w}$ niej udziału ani królowa Jadwiga (wraz z najważniejszymi panami królestwa wyruszyła w 1387 r. z wyprawą na Ruś Halicką w celu usunięcia z niej węgierskich starostów i przyłączenia na powrót do Korony), ani najwyżsi dostojnicy polskiego Kościoła. Jagielle towarzyszył jedynie Andrzej herbu Jastrzębiec, biskup w mołdawskim Serecie, oraz grupa niższych duchownych. Jagiełło najpierw utworzył w Wilnie i hojnie uposażył pierwsze biskupstwo (przywilej z 17 lutego 1387 r.). Kolejny etap chrystianizacji miał miejsce podczas zjazdu bojarów w Wilnie (22 lutego 1387 r.), a wiosną tego roku król rozpoczął objazd Litwy i chrzest prostego ludu. Długosz wspomina, że Jagiełło, mimo oporu Litwinów, „ów ogień, miany za wieczysty w Wilnie, głównym mieście i stolicy Litwy, utrzymywany i strzeżony przez kapłana, zwanego w ich języku «znicz», który modlącym się i żądającym przepowiedni rzeczy przyszłych fałszywe ogłaszał wyrocznie, jakoby od bóstwa mu zwierzone, [...] kazał wobec przytomnych pogan zgasić, a świątynię i ołtarz, na którym czyniono ofiary, zburzyć. Nadto gaje i ogrody, uważane za święte, kazał powycinać oraz pozabijać węże i żmije, które po domach nawet jakoby bóstwa żywiono i czczono. Barbarzyńcy zaś zawodzili przy tym żale nad upadkiem i zelżeniem tych fałszywych bożyszcz, nie śmiejąc sarkać przeciw nakazom króla. [...] Po zburzeniu i zniszczeniu bóstw pogańskich, gdy Litwini poznali naocznie ich fałszywość, którą dotychczas się łudzili, ulegli wreszcie i z pokorą skłonili się do przyjęcia wiary chrześcijańskiej, wyrzekając się dawnych błędów. W dniach kilkunastu od kapłanów polskich, a jeszcze więcej od króla Władysława, który umiał ich język i którego chętniej słuchali, wyuczeni głównych zasad do wierzenia podanych, czyli Artykułów Wiary, Składu Apostolskiego i Modlitwy Pańskiej, przystąpili do chrztu świętego. A Władysław, król pobożny, rozdawał prostemu ludowi odzież, koszule i nowe ubrania z sukna przywiezionego na to z Polski”, Jan Długosz, Roczniki czyli Kroniki Sławnego Królestwa Polskiego. Księga dziesiąta 13701405, przeł. J. Mrukówna, red. i koment. Z. Perzanowski, Warszawa 1981, s. 210-211.

${ }^{39}$ Chodzi tutaj o bitwę pod Grunwaldem (15 lipca 1410 r.), która w rzeczywistości była serią potyczek toczonych w różnych miejscach, angażujących po stronie 
stoletniego panowania pozostawił jako dziedziców dwóch synów. Starszy z nich, Władysław, wezwany został (tak wielka była sława cnót Jagiellonów) do objęcia władzy królewskiej nie tylko nad Polską, ale także nad Węgrami ${ }^{40}$. Tam w ciągu dziewięciu ${ }^{41}$ lat panowania odniósł wiele zwycięstw nad Turkami ${ }^{42}$, odwiecznymi wrogami

polsko-litewskiej ponad trzydzieści tysięcy rycerzy, po stronie krzyżackiej - dwadzieścia tysięcy. W zakończonej klęską Krzyżaków bitwie zginęli między innymi wielki mistrz zakonu Ulrich von Jungingen, kilkudziesięciu komturów oraz kilkanaście tysięcy rycerzy zakonnych, a Polacy zdobyli kilkadziesiąt chorągwi krzyżackich. Być może właśnie tych komturów miał na myśli Hozjusz, gdy podał tak mało spektakularną liczbę pięćdziesięciu zabitych wrogów, a być może chodziło o przesadzoną liczbę pięćdziesięciu tysięcy. 14 lub 15 lipca oddziały polskie zdobyły, złupiły i spaliły Dąbrowno (niem. Gilgenburg), bogate i mocno obwarowane miasto krzyżackie położone pomiędzy dwoma jeziorami, Dąbrową Wielką i Małą. Oprócz bogatych łupów - jak odnotowuje Długosz - wzięto wielu jeńców, z których król Władysław Jagiełło zatrzymał jedynie mnichów krzyżackich i miejscową szlachtę, „wypuścił zaś z niewoli wszystkich mieszkańców miasta, lud, chłopów, również wszystkie kobiety i dziewczęta i wszystkie niewiasty wszelkiego stanu”, Jan Długosz, Roczniki czyli Kroniki Sławnego Królestwa Polskiego. Księga dziesiąta i jedenasta (1406-1412), [przeł. J. Mrukówna, oprac. D. Turkowska, M. Kowalczyk, red. i koment. J. Garbacik, K. Pieradzka], Warszawa 1982, s. 98.

40 Władysław III Warneńczyk (1424-1444) - od 1434 roku król Polski, w 1440 roku sejm węgierski wybrał go na władcę Węgier. Warunkiem było poślubienie Elżbiety, wdowy po królu Albrechcie. Fakt, że urodziła ona po śmierci męża syna Władysława, zwanego Pogrobowcem, sprawił, że Elżbieta wycofała się z planowanego małżeństwa $z$ Jagiellonem. Doprowadziła nawet do koronacji swego syna, jednak nie udało się jej zająć Budy, do której wkroczył Władysław III i przyjął tam koronę zdjętą $\mathrm{z}$ relikwiarza św. Stefana. W tej trudnej sytuacji roli mediatora podjął się legat papieża Eugeniusza IV, kardynał Giuliano Cesarini (1398-1444), wysłany do Budy w celu zorganizowania krucjaty przeciw Turkom atakującym południe Węgier. Sukces tej kampanii miał pomóc papieżowi Eugeniuszowi IV (1383-1447, papież od 1431 r.), usuniętemu w 1493 roku z urzędu postanowieniem Soboru Bazylejskiego, odbudować autorytet i odzyskać utraconą władzę. Krucjata spotkała się z nikłym odzewem w Europie i zakończyła się klęską pod Warną 10 listopada 1444 roku. W bitwie zginął młody król Władysław, w trakcie odwrotu poległ również kardynał Cesarini.

${ }^{41}$ Jest to pomyłka, wynikająca zapewne z zawodności ludzkiej pamięci. Hozjusz prawdopodobnie potraktował łącznie panowanie Władysława III w Polsce i na Węgrzech, które obejmowało nie dziewięć, ale dziesięć lat.

${ }^{42}$ Armia węgierska pod wodzą Jánosa Hunyadego początkowo odnosiła wiele zwycięstw nad Turkami, jednak o ostatecznym pokonaniu wroga nie mogło być 
narodów chrześcijańskich. Osłabił ich siły do tego stopnia, że zmusił ich, by poprosili o pokój czy raczej zawieszenie broni. Chociaż na to przystano, jednak gdy tylko papież Eugeniusz IV za pośrednictwem legata Juliusza Cezariniego wezwał [króla] do wznowienia wojny przeciw Turkom, bez zwłoki (tak wielka była cześć dla Stolicy Apostolskiej, tak wielkie posłuszeństwo w wypełnianiu jej nakazów) starł się z Turkami i nie wahał się nawet umrzeć za Chrystusa. Walczył bowiem dzielnie razem $\mathrm{z}$ legatem papieskim. I chociaż na początku zwycięstwo było po jego stronie, na koniec jednak pokonany poległ, zostawiając jako dziedzica Królestwa Polskiego brata Kazimierza ${ }^{43}$, dziada zmarłego dopiero co króla. Ten pojął za żonę Elżbietę ze znakomitego domu austriackiego, córkę Albrechta, króla rzymskiego, niewiastę nadzwyczajnej pobożności ${ }^{4}$. Uposażyła ona i upiększyła

mowy. Sułtan Murad II rozpoczął rokowania pokojowe zwieńczone podpisaniem 12 czerwca 1444 roku w Adrianopolu dziesięcioletniego pokoju na korzystnych dla Węgier warunkach. Król Władysław III nieoczekiwanie, za namową Cesariniego, zerwał umowę. 4 sierpnia 1444 roku ogłosił w Segedynie manifest wojenny i, mimo nikłego odzewu, ruszył do walki zakończonej klęską pod Warną.

${ }^{43}$ Kazimierz IV Jagiellończyk (1427-1492) - najmłodszy syn Władysława Jagiełły i Sonki Holszańskiej; od 1440 roku wielki książę litewski, a od 1447 król Polski; władca zdolny i energiczny. Za jego panowania Polska pokonała zakon krzyżacki w tak zwanej wojnie trzynastoletniej, zakończonej pokojem toruńskim (1466), na mocy którego państwo krzyżackie zostało podzielone na część przyłączoną do Polski (Prusy Królewskie) oraz część zakonną (Prusy Krzyżackie), zależną od Polski (wielki mistrz został zobowiązany do składania przysięgi wierności polskiemu królowi). W 1454 roku Kazimierz zawarł polityczny mariaż z Elżbietą Habsburg zwaną Rakuszanką, z którą miał trzynaścioro dzieci. Za jego panowania dynastia Jagiellonów stała się jednym z czołowych domów panujących w Europie.

${ }^{44}$ Elżbieta Rakuszanka (1436/37-1505) - „córka, siostra, żona i matka królów” - jak kazała wyryć na nagrobku swojego syna Jana Olbrachta - była córką króla Niemiec i Węgier Albrechta II Habsburga i Elżbiety Luksemburskiej i wnuczką po kądzieli Zygmunta Luksemburskiego. Jej bratem był Władysław Pogrobowiec, król Czech i Węgier, po którego śmierci w 1457 roku stała się dziedziczką obu królestw. W 1454 roku została żoną króla Kazimierza Jagiellończyka. Małżeństwo układało się harmonijnie i doczekało się, jak wspomniano, trzynaściorga dzieci. Czterech z sześciu synów zostało królami, a pięć córek poprzez odpowiednie małżeństwa skoligaciło dom jagielloński z większością panujących w Europie dynastii. Elżbieta 
krakowską świątynię nader wieloma darami. Zapoczątkowała także to, że każdego dnia w kaplicy kościoła katedralnego, którą sama zbudowała i wyposażyła ${ }^{45}$, śpiewano mszę o męce Pańskiej oraz godzinki o tym samym ${ }^{46}$. Z nią [Kazimierz] miał sześciu synów ${ }^{47}$ i sie-

Rakuszanka była inteligentna i wykształcona, miała duży wpływ na politykę męża. Otaczała opieką pisarzy i artystów. Cechowała ją gorliwa religijność. Hojnie wspierała Kościół. W katedrze wawelskiej na przykład ufundowała kaplicę pod wezwaniem Bożego Ciała i św. Andrzeja dla swego ukochanego syna Jana Olbrachta zmarłego w 1501 roku oraz kaplicę Świętokrzyską.

${ }^{45}$ To jest kaplicę pod wezwaniem św. Krzyża (Świętokrzyską), dobudowaną w trzeciej ćwierci XV wieku do zachodniej fasady katedry na Wawelu. Kaplica ta stała się miejscem spoczynku króla Kazimierza Jagiellończyka. Nakryty baldachimem sarkofag monarchy wykonał z czerwonego marmuru Wit Stwosz. W kaplicy znajdują się też dwa tryptyki uchodzące dzisiaj za arcydzieła malarstwa średniowiecznego, wykonane w pracowniach krakowskich mistrzów. Są to: tryptyk Matki Boskiej Bolesnej i Chrystusa Bolesnego ze scenami z życia Marii i jej Syna (czwarta ćwierć XV w.) oraz tryptyk Świętej Trójcy (1467); Krakowska katedra na Wawelu. Przewodnik dla zwiedzających, oprac. M. Rożek, zdjęcia A. Bujak, Kraków 1987, poz. 29.

${ }^{46}$ Godzinki o męce Pańskiej (Horae canonicae Salvatoris) - skrót nabożeństwa brewiarzowego, przeznaczony do odśpiewywania dla osób świeckich. Cechuje je prosty układ i styl wzorowany na oficjum kościelnym. Składa się z siedmiu części, powiązanych z kolejnymi epizodami męki Pańskiej. Jutrznia zatem przypomina pojmanie w Ogrójcu, pryma - sąd u Piłata, tercja - biczowanie i cierniem ukoronowanie, seksta - drogę krzyżową na Kalwarię, nona - śmierć na krzyżu, nieszpory zdjęcie z krzyża, kompleta - złożenie do grobu. Godzinki szczególnie popularne stały się w drugiej połowie XV wieku, kiedy nasiliła się nowa fala religijności ludowej propagowanej przez franciszkanów.

47 Byli to: 1) Władysław (1456-1516), od 1471 roku król Czech, a od 1492 także Węgier. 2) Kazimierz (1458-1484), uważany za najzdolniejszego z wszystkich synów Kazimierza Jagiellończyka, zmarł jednak w wieku niespełna dwudziestu sześciu lat wskutek gruźlicy. Był niezwykle religijny. Legenda powstała tuż po jego śmierci głosiła, że Kazimierz w czasie swojego pobytu w Wilnie (od połowy maja 1483 r.) zimą przed świtem wymykał się do kościoła i klęczał przed zamkniętymi jeszcze drzwiami. Jego ulubioną modlitwą miał być hymn maryjny św. Bernarda Omni die. Wspierał ubogich. Został pochowany w katedrze wileńskiej w kaplicy Najświętszej Marii Panny, wzniesionej dla syna przez króla Kazimierza Jagiellończyka. Dzięki staraniom brata, króla Zygmunta Starego, Kazimierz został kanonizowany w 1523 roku, lecz bulla nie dotarła do Polski. Ponowna kanonizacja odbyła się w 1602 roku. 3) Jan Olbracht (1459-1501), po śmierci ojca (1492) wybrany na króla Polski. 4) Po 
dem córek $^{48}$. Najstarszy z nich, Władysław, jeszcze za życia ojca został wyznaczony najpierw na króla Czech, wkrótce potem Węgier. $Z$ tego każdy może łatwo się domyślić, jaki mir miał ród Jagiellonów wśród innych narodów. Drugi w kolejności był Jan Olbracht. Zastąpił ojca na tronie królestwa po czterdziestu pięciu latach jego panowania. Gdy po nieco ponad ośmiu latach rządów umarł, na króla Polski wybrany został Aleksander. Po zaledwie pięciu latach, odkąd objął ster państwa, za największą zgodą wszystkich władzę królewską powierzono Zygmuntowi, ojcu tego, dla którego słusznie teraz to nabożeństwo sprawujemy. Pobożność królowej Elżbiety sprawiła zaś, że (takie szczęście rzadko zdarzało się jakiejkolwiek matce), gdy sama była córką króla rzymskiego Albrechta ${ }^{49}$, siostrą króla Węgier Władysława, żoną króla Polski Kazimierza, ujrzała czterech synów koronowanych na władców trzech państw: Węgier, Czech i Polski. Tak więc słusznie można o niej powiedzieć, że była wspaniałą matką synów. Albowiem prócz czterech królów miała jeszcze dwóch synów odznaczających się pobożnością: Fryderyka, kardynała tytularnego

bezpotomnej śmierci Jana Olbrachta królem Polski został Aleksander (1461-1506); 5) po nim zaś korona polska przypadła Zygmuntowi (1468-1548), ojcu Zygmunta II Augusta. 6) Najmłodszego Fryderyka (1468-1503) ojciec przeznaczył do kariery duchownej, by uzyskać większy wpływ na Kościół w Polsce. W wieku dwudziestu lat Fryderyk otrzymał biskupstwo krakowskie (1488), a w pięć lat później stał się najważniejszym dostojnikiem kościelnym w państwie, obejmując godność prymasa. W 1493 roku wyniesiony został przez papieża Aleksandra VI do godności kardynalskiej. Pomimo dość swobodnego trybu życia sumiennie wypełniał swoje obowiązki $\mathrm{w}$ powierzonych mu diecezjach. Był oddany państwu i dynastii.

${ }^{48}$ Jadwiga (1457-1502) wyszła za księcia bawarskiego Jerzego Bogatego Wittelsbacha; Zofia (1464-1512) została wydana za margrabiego brandenburskiego Fryderyka Hohenzollerna; Anna (1476-1503) poślubiła księcia pomorskiego Bogusława X; Barbara (1478-1534) - księcia saskiego Jerzego Brodatego Wettina; Elżbietę (1483-1517) wydano za księcia legnickiego Fryderyka II Piasta. Dwie pozostałe (obie nosiły imię Elżbieta) zmarły w dzieciństwie.

49 Albrecht II Habsburg (1397-1439) - książę austriacki, od 1438 roku król Niemiec; był zięciem cesarza Zygmunta Luksemburskiego, po którym odziedziczył w 1437 roku koronę Czech i Węgier. 
[kościoła] pod wezwaniem św. Łucji przy Septisolium ${ }^{50}$, i Kazimierza, którego cechowała nadzwyczajna świętość życia i który zasłynął wieloma cudami. Musiałbym tu wiele powiedzieć o Kazimierzu, dziadku zmarłego króla, mężu wielkiej pobożności, sławnym także z wielu zwycięstw, oraz o jego stryjach. Poprzestanę [jednak] na powiedzeniu kilku słów o ojcu, bo mowa [zanadto] przeciągnęłaby się. Tak wielka była bowiem jego roztropność, tak wielka bezstronność i sprawiedliwość, tak wielka łagodność, tak wielkie powodzenie w prowadzeniu wojen (mówi się, że wyszedł zwycięsko z czterdziestu bitew), że niewielu jest władców tego czasu, którzy mogliby z nim się równać, a już z największym trudem go przewyższyćs1. A cóż powinienem powiedzieć o jego religijności? Wydaje się, że przewyższył w niej wszystkich pozostałych. Okazywał bowiem wielką przychylność stanowi kapłanów i biskupów. Nie zaniechał, jak długo starczyło mu sił, by każdego dnia iść do kościoła, choćby oddalonego od jego siedziby, i z największą pokorą uczestniczyć w nabożeństwie.

${ }^{50}$ Septisolium (Septizodium) - monumentalna świątynia siedmiu bóstw planetarnych wzniesiona na południowym zboczu Palatynu przez Septymiusza Sewera (budowę ukończono w 203 r.). Pozostałości tego gmachu podziwiali jeszcze piętnasto- i szesnastowieczni artyści i wielbiciele antyku. Kazał je zburzyć papież Sykstus V (p. 1585-1590), a uzyskany marmur wykorzystano jako budulec nowych obiektów powstających na terenie Rzymu. Zob. R. Hughes, Rzym, przeł. W. Jeżewska, Warszawa 2016, s. 246.

${ }^{51}$ Na panowanie Zygmunta I Starego (1506-1548) przypadły wojny: z Moskwą (1507-1508, 1512-1522), w czasie których wojska polskie odniosły między innymi wspaniałe zwycięstwo pod Orszą; z Mołdawią (1509-1510, 1530-1531), zakończone wiktorią pod Obertynem, i z zakonem krzyżackim (1519-1521). Finałem konfliktu z Prusami był hołd lenny złożony Zygmuntowi w 1525 roku przez Albrechta II Hohenzollerna. Czterdzieści jeden lat rządów Zygmunta Starego było okresem wielkiego rozkwitu kulturalnego Polski. Monarcha skupiał na swoim dworze rzesze cudzoziemskich i polskich architektów, malarzy, rzeźbiarzy, rzemieślników, a także pisarzy i muzyków. Zlecił między innymi rozbudowę zamku na Wawelu w nowym renesansowym stylu, budowę kaplicy nazwanej później Zygmuntowską (15191533) pod kierunkiem Bartolomea Berrecciego. 
Podczas zaś tego tygodnia, który nazywamy świętym ${ }^{52}$, spędzał w kościele niemal całe dnie, nie zajmując się żadnymi innymi sprawami prócz oddawania czci Bogu. Gdy w środku nocy przychodził na poranne modły, wracał do pałacu dopiero przed południem, spędziwszy w kościele około dziesięciu godzin. Ponadto od dnia, w którym czczono pamięć złożenia Chrystusa do grobu ${ }^{53}$, aż do dnia Zmartwychwstania wstrzymywał się od wszelkiego pokarmu. Nie poprzestawał na przestrzeganiu postów nałożonych przez Kościół, lecz także w każdą sobotę jadł tylko suchy chleb, co Grecy nazywają „suchym jedzeniem”, i pił tylko wodę aż do czterdziestego roku życia; wzorem ojca gasił pragnienie, nie pijąc - jak czytamy o nich obydwu - ani wina, ani cydru ${ }^{54}$. Gdybym chciał przypomnieć wszystkie nadzwyczajne cnoty tego króla, nie starczyłoby dnia. Z takiego ojca, który - jak się zdaje - dopełnił miary wszystkich cnót, zrodzony został ten, dla uczczenia pamięci którego dzisiaj się tu zgromadziliście i z powodu którego bolejemy, że spadła korona z jego głowy. Ten był ósmym i przede wszystkim ostatnim królem ze sławnego rodu Jagiellonów, tak więc korona zostanie zapewne przeniesiona $\mathrm{z}$ tego domu do innego. Miał dostojną matkę ${ }^{55}$, córkę Jana Galeazza Sforzy,

52 Wielki Tydzień - ostatni tydzień Wielkiego Postu: od Niedzieli Palmowej, podczas której obwożono w procesjach drewnianą postać Chrystusa na ośle, do Wielkiej Soboty. Tego dnia odwiedzano urządzone w kościołach groby Jezusa.

53 To znaczy od Wielkiego Piątku.

${ }^{54}$ W podobny sposób o wstrzemięźliwości króla Zygmunta Starego i jego ojca wspomina blisko związany z Hozjuszem Marcin Kromer w łacińskiej mowie pochwalnej, którą napisał na okoliczność pogrzebu monarchy - zob. M. Kromer, Mowa na pogrzebie Zygmunta I, w: idem, Mowa na pogrzebie Zygmunta I oraz O pochodzeniu i o dziejach Polaków księgi XXIX i XXXX, wstęp, przeł. i oprac. J. Starnawski, Olsztyn 1982, s. 139. Mowa ta została opublikowana w 1550 roku w Moguncji razem z łacińskim przekładem polskiej mowy, którą wygłosił podczas pogrzebu monarchy biskup krakowski Samuel Maciejowski. Uważa się, że autorem tego przekładu był Hozjusz. Być może współpracował z nim Kromer. Zob. K. Mecherzyński, Historya wymowy w Polsce, t. 1, Kraków 1856, s. 471; S. Starnawski, Wstęp, w: M. Kromer, Mowa na pogrzebie..., s. XX.

55 W oryginale: „Matrem bonam habuit” - być może mamy tu do czynienia z błędem drukarza i zdanie to powinno mieć postać: „Matrem Bonam habuit”. Bona 
księcia Mediolanu, ze związku z Izabeląa ${ }^{56}$, której dziad po kądzieli, Alfons, drugi tegoż imienia król Neapolu, pochodził z pnia aragońskiego i królów sycylijskich ${ }^{57}$. $\mathrm{Z}$ tego rodu wywodzili się po matce także godni wiecznej pamięci cesarz Karol $\mathrm{V}^{58}$ i Ferdynand ${ }^{59}$. Wraz z naszym zmarłym królem spadła korona i całkowicie zakończyła się

Sforza d'Aragona (1494-1557) - córka Gian Galeazza Sforzy, księcia Mediolanu, i Izabeli Aragońskiej; w 1518 roku została żoną Zygmunta I Starego i królową Polski. Była kobietą energiczną. Dążyła do umocnienia władzy królewskiej i dynastii Jagiellonów.

${ }^{56}$ Izabela Aragońska (1470-1524) - księżna Mediolanu i Bari; córka króla Neapolu i Sycylii Alfonsa II i jego pierwszej żony, Hipolity Marii Sforzy. Ród Aragonów łączyło pokrewieństwo z najznakomitszymi domami panującymi w Europie. Ciotecznym wujem Izabeli był cesarz Maksymilian I, który w 1492 roku poślubił Biankę Marię Sforzę, córkę Gian Galeazza Marii Sforzy, wuja Izabeli. Ze związku ze swoim kuzynem Gian Galeazzem Sforzą Izabela miała czworo dzieci, z których tylko Bona Maria, przyszła królowa Polski, przeżyła dzieciństwo i dożyła zaawansowanego wieku. Księżna Izabela doświadczyła trudnych chwil, gdy rozgorzała walka o władzę we Włoszech pomiędzy Francją i Hiszpanią. Jej słaby, zdegenerowany małżonek zmarł w 1494 roku, wcześniej ubezwłasnowolniony i pozbawiony władzy przez stryja Lodovica il Moro. Ostatecznie uzyskała w 1502 roku od króla Ferdynanda Katolickiego uznanie jej praw do księstw Bari i Rossano (część Królestwa Neapolitańskiego).

${ }^{57}$ Alfons II z dynastii Trastámara (1448-1495) - syn Ferdynanda I Aragońskiego, króla Neapolu oraz Sycylii, i Isabelli de Clermont. Władzę nad Neapolem i Sycylią objął pod koniec życia, w 1494 roku. Po matce odziedziczył prawo tytułowania się królem Jerozolimy. Był kuzynem obojga katolickich królów Hiszpanii - króla Aragonii Ferdynanda II i jego żony, królowej Kastylii Izabeli I. Ze związku z Hipolitą Marią Sforzą miał troje dzieci: Ferdynanda (1469-1496), który przejął po nim sukcesję, Izabelę (1470-1524), matkę królowej Bony, i Piotra (1472-1497), księcia Rossano.

${ }^{58}$ Karol V (1500-1558) - syn Filipa I Pięknego i Joanny Szalonej (Joanna była trzecim dzieckiem Ferdynanda Aragońskiego i Izabeli Kastylijskiej); od 1516 roku był królem Hiszpanii (jako Karol I), od 1519 do 1556 - cesarzem rzymsko-niemieckim. Jako dziedzic trzech dynastii (habsburskiej, burgundzkiej i kastylijsko-aragońskiej) dążył do odrodzenia monarchii uniwersalnej. Jego plany udaremniła Francja. Umocnił za to swoją władzę w Hiszpanii i we Włoszech. Nie powiodły się też jego próby umocnienia autorytetu cesarza w Niemczech. Zniechęcony niepowodzeniami i chory abdykował w 1556 roku, przekazując swe dziedziczne posiadłości w Niemczech i koronę cesarską bratu Ferdynandowi I, zaś władzę w Hiszpanii, Włoszech i Niderlandach - synowi Filipowi II.

${ }^{59}$ Ferdynand I (1503-1564) - brat i następca Karola V. W roku 1521 został królem Austrii, w 1526 otrzymał koronę Czech i Węgier, a w 1556 został cesarzem. 
[władza] Jagiellonów, ponieważ nie pozostał już nikt prócz czterech jego sióstr ${ }^{60}$. Przodków zaś swoich ten nasz Zygmunt August próbował jeśli nie przewyższyć, to przynajmniej dorównać im w cnocie, jako że Bóg obsypał go wieloma wspaniałymi darami. Odznaczał się doskonałymi obyczajami, wspaniałą wymową i nadzwyczajną roztropnością, tak że ilekroć przybywali posłowie innych władców i gdy bez pośredników toczyli z nim rozmowy, nie mogli się nadziwić jego roztropności w udzielanych odpowiedziach. Do tego dochodziła osobliwa uprzejmość i życzliwość oraz nadzwyczajna łagodność usposobienia. Był wolny od wszelkiej pychy, tak że nawet strojem niemal nie różnił się od osób prywatnych. Senatorom swojego państwa, zwłaszcza biskupom, którzy zajmują pierwsze miejsce w radzie królewskiej, zawsze okazywał wielkie poważanie, szanował ich jak ojców. Uważał ich bowiem za godnych tego miana. W poważniejszych sprawach nie postanawiał niczego, zanim się z nimi nie naradził. W rezultacie, podczas gdy w bardzo wielu prowincjach chrześcijańskich wybuchały wielkie i poważne niekiedy niepokoje oraz rozruchy, samą Polską nie wstrząsnęło nic takiego przez czterdzieści dwa lata jego panowania. Wszelkimi sposobami starał się pozyskać przychylność sąsiednich królów i książąt. I ponieważ jego ojciec wywodził swój ród po kądzieli z domu, od którego nie ma znakomitszego na świecie, a mianowicie $\mathrm{z}$ austriackiego, on [również] pragnął, zacieśniwszy z nim więzy krwi, spłodzić jakiegoś małego Jagiellona. Lecz wskutek grzechów naszych stało się, że chociaż za

60 Najstarsza córka ze związku Bony i Zygmunta Starego, Izabela (1519-1559), żona Jana Zápolyi, króla Węgier, nie żyła już od ponad dziesięciu lat. Pozostałe to: Jadwiga (1513-1573), córka Zygmunta Starego z pierwszego małżeństwa z Barbarą Zápolyą (1512-1515), żona elektora brandenburskiego Joachima Hohenzollerna; Zofia (1522-1572), wydana za księcia Brunszwiku Henryka II (1556); Anna (1523-1596) - po śmierci Zygmunta Augusta została żoną Stefana Batorego i królową Polski (1576-1586); najmłodsza, Katarzyna Jagiellonka (1526-1583), poślubiła Jana Wazę (1562), księcia Finlandii i późniejszego króla Szwecji. Jedyny brat Zygmunta Augusta, Olbracht, syn Zygmunta Starego i Bony, zmarł po przedwczesnych narodzinach (1527). 
przykładem swojego dziada Kazimierza pojął za żonę córkę, a także siostrę cesarza, jednak Bóg nie dał jej tego szczęścia, by także o niej można było powiedzieć, że jest wspaniałą matką choćby jednego tylko syna ${ }^{61}$. Niemniej [nasz król] uczynił wszystko, by wszelakimi przysługami zachować przyjaźń tego znakomitego domu, jaką darzyli go najjaśniejsi cesarze Ferdynand i Maksymilian ${ }^{62}$. Była ona tak wielka, że gdy wybuchł wielki spór pomiędzy obydwoma cesarzami a jego siostrzeńcem o królestwo Węgier, nie chcieli innego rozjemcy dla uśmierzenia tej waśni jak tylko króla Zygmunta Augusta, którego dotyczy ta mowa ${ }^{63}$. Za jego staraniem półtora roku temu wszystkie

${ }^{61}$ Hozjusz wspomina tutaj o dwóch żonach Zygmunta Augusta, córkach cesarza Ferdynanda i siostrach późniejszego cesarza Maksymiliana II: Elżbiecie (1526-1545), którą monarcha poślubił w 1543 roku, i jej młodszej siostrze Katarzynie (1533-1572), wdowie po księciu Mantui Franciszku III Gonzadze. To drugie małżeństwo zostało zawarte w 1553 roku. Oba związki nie układały się dobrze, zwłaszcza z królową Katarzyną. Zygmunt August usiłował się z nią rozwieść, czemu zdecydowanie sprzeciwiał się Hozjusz, starając się bezskutecznie doprowadzić do pojednania pary królewskiej. Ostatecznie Katarzyna wyjechała z Polski w 1566 roku, osiadła w Linzu, gdzie zmarła w 1572 roku na kilka miesięcy przed swoim małżonkiem. Oba małżeństwa były bezpotomne. Kardynał przemilcza natomiast zawarte w 1547 roku potajemnie, niefortunne małżeństwo z poddanką, Barbarą Radziwiłłówną (1520/1523-1551), wdową po wojewodzie trockim Gasztołdzie, z którą król również nie miał żadnego potomstwa.

${ }^{62}$ Maksymilian II (1527-1576) - syn cesarza Ferdynanda I i Anny, córki Władysława Jagiellończyka. Po śmierci ojca w 1564 roku objął tron cesarski. Wcześniej został królem Niemiec i Czech (1562) oraz Węgier (1563).

${ }^{63}$ Chodzi tu o sprawę Jana Zygmunta Zápolyi (1540-1571), syna króla Węgier Jana Zápolyi i starszej siostry Zygmunta Augusta, Izabeli. W 1538 roku Jan Zápolya zawarł układ z Ferdynandem I w Wielkim Waradynie, na mocy którego Węgry zostały podzielone pomiędzy niego i Ferdynanda. Zápolya zachował dożywotni tytuł króla węgierskiego, ale jego ewentualni synowie tracili prawa do korony. W 1539 roku Zápolya poślubił Izabelę, a rok później zmarł, wkrótce po narodzinach ich syna Jana Zygmunta, którego szlachta węgierska wbrew magnatom i postanowieniom wielkowaradyńskim obwołała królem Węgier. Od tego czasu Izabela, aż do swej śmierci w 1559 roku, a po niej sam Jan Zygmunt ze zmiennym szczęściem prowadzili działania zmierzające do odzyskania i utrzymania władzy na Węgrzech. Nie mogli przy tym liczyć ani na poparcie Zygmunta Starego, uznającego umowę wielkowaradyńską, ani Zygmunta Augusta, który na początku swego samodzielnego panowania zawarł 
spory zakończono. Sprawa ta osiągnęła taki finał, jakiego pragnął cesarz. Związek pomiędzy cesarzem a siostrzeńcem [naszego] króla nawet zacieśniłby się, gdyby ten ostatni wcześniej nie został zabrany $\mathrm{z}$ tego życia.

Gdy zaś słucha się pochwał czynów wojennych, zdają się one rozbrzmiewać okrzykami żołnierzy i dźwiękiem trąb. [Ale] w świętym miejscu nie należy o tym wiele mówić. [Król Zygmunt August] wszystkie swoje myśli i troski kierował ku jednej rzeczy - by zachować pokój i zgodę. I przed niczym nie wzdragał się bardziej niż przed rozlewem krwi - do tego stopnia, że nawet jeśli trzeba było wydać wyrok śmierci na kogoś oskarżonego o zbrodnię taką karą zagrożoną, czynił to bardzo niechętnie i zawsze okazywał wielki smutek. Jeśli jednak ktoś wezwałby go na wojnę, nie pozwolił sobie zaniedbać żadnego obowiązku dzielnego i wielkiego władcy. W kilku mniejszych bitwach pokonał Rusinów, Tatarów i Wołochów najeżdżających jego ziemie, niewielkimi oddziałami zwyciężając nierzadko ogromne siły wroga ${ }^{64}$.

w Pradze w 1549 roku traktat z Ferdynandem, w którym (w imieniu króla rozmowy prowadził Hozjusz) zobowiązał się do nieangażowania się w sprawy węgierskie. Uczynił to dopiero w latach 50., gdy zaistniały sprzyjające okoliczności do powrotu Izabeli wygnanej w 1551 roku do Siedmiogrodu. Przez posła Marcina Kromera Zygmunt August zwrócił się do Ferdynanda, by dla dobra Węgier zagrożonych przez Turków zgodził się na powrót Izabeli oraz jej syna i przekazał im Siedmiogród, co nastąpiło w 1556 roku. Po powrocie Izabela starała się zbrojnie odzyskać dla syna ziemie zajęte przez Ferdynanda, ale poniosła klęskę. Podjęła wówczas rokowania pokojowe z Ferdynandem, ale i one nie przyniosły rezultatów. Izabela zmarła we wrześniu 1559 roku. Po jej śmierci Zygmunt August rozpoczął na rzecz swego siostrzeńca długotrwałe pertraktacje z Habsburgami w sprawie Siedmiogrodu. Ich efektem było porozumienie zawarte w Spirze w sierpniu 1570 roku pomiędzy Janem Zygmuntem Zápolyą a Maksymilianem II. Jan Zygmunt zrzekł się tytułu króla Węgier i został pierwszym księciem Siedmiogrodu, gdzie miał władać dożywotnio. Miał również zawrzeć małżeństwo z siostrzenicą cesarską, księżniczką Clèves. Jan Zygmunt Zápolya zmarł cztery dni po ratyfikacji układu, 14 marca 1471 roku.

${ }^{64} \mathrm{~W} 1549$ roku Tatarzy zaatakowali ziemie ruskie i podolskie, paląc i niszcząc wiele osad, biorąc w jasyr lub mordując miejscową ludność. Spalono między innymi Peremirkę na Wołyniu należącą do kniazia Iwana Wiśniowieckiego, a jego samego 
Zdobył znany, należący do Moskwy gród Ułłę ${ }^{65}$, dołączył do swoich tytułów [tytuł pana] Inflant ${ }^{66}$, [ziemi] z wieloma miastami, małymi miasteczkami i kilkoma uczęszczanymi portami. Z całych sił zabiegał, by królestwo, które przejął od ojca kwitnące, przekazać swoim następcom w jeszcze lepszym stanie. I to także z łaski Boga osiągnął. Albowiem za jego panowania wzrosły majątki ludzi prywatnych, tak że Polska, gdy on dzierżył ster królestwa, nigdy bardziej nie opływała w dostatek (oby Bóg zechciał, by trwało to na wieki). Nigdy też nie widziano w niej większego splendoru i elegancji. Ponadto skarbiec, który przejął niemały, pozostawił bardziej zasobny, chociaż w hojności i szczodrości, nie tylko dla swoich, ale też o wiele bardziej dla obcych, nie ustępował żadnemu z królów. Przeciwnie, nie zaniechał niczego, jeśli uznał, że przydałoby to blasku i godności jego władzy albo wiązałoby się z obroną królestwa. Albowiem zadbał o wzniesienie wielkim kosztem kilku zamków obronnych, okazałych gmachów oraz o budowę wspaniałej świątyni w Wilnie ${ }^{67}$. Był szczodry i hojny przede wszystkim dla tych,

z żoną wzięto do niewoli. Ataki te odpierał hetman Jan Tarnowski, który odniósł wiele zwycięstw za panowania Zygmunta Starego.

${ }^{65}$ Zadanie zdobycia tego warownego miasta u ujścia Ułły (Ulanki) do Dźwiny (dzisiejsza północna Białoruś) początkowo Zygmunt August powierzył staroście żmudzkiemu Hieronimowi Chodkiewiczowi. Oblężenie nie przyniosło oczekiwanego rezultatu i pochłonęło wiele ofiar. Wówczas dowództwo przejął hetman polny Roman Sanguszko, który uśpił czujność przeciwnika, pozorując zaniedbania w oblężeniu, i brawurowym szturmem zdobył Ułłę pod koniec września 1568 roku. Wziął do niewoli wielu jeńców. Zob. Słownik geograficzny Królestwa Polskiego i innych krajów stowiańskich, red. B. Chlebowski, t. 12, Warszawa 1892, s. 789.

${ }^{66}$ Inflanty (łac. Livonia) - historyczna kraina nad Dźwiną i Zatoką Ryską, od XIII wieku pozostająca we władaniu niemieckiego zakonu rycerskiego kawalerów mieczowych. W 1561 roku zakon został zsekularyzowany, a wielki mistrz Gotthard Kettler poddał Inflanty pod zwierzchność króla polskiego Zygmunta II Augusta. Ziemie te - $z$ wyłączeniem Kurlandii i Semigalii, oddanych w lenno Kettlerowi, oraz północnej części Estonii, pozostałej przy Szwecji - stały się po unii lubelskiej (1569) obok Korony Królestwa Polskiego i Wielkiego Księstwa Litewskiego trzecią częścią składową Rzeczypospolitej Obojga Narodów jako wspólna własność Polski i Litwy.

${ }^{67}$ Król Zygmunt August prowadził wiele przedsięwzięć budowlanych. Z jego polecenia w latach 1544-1547 zmodernizowano Stary Zamek w Kamieńcu Podolskim, 
którzy górowali nad innymi wiedzą, i powierzał im godności kościelne, szczególnie zaś dla tych, którzy byli biegli w naukach humanistycznych. Z tego [też] powodu te studia najbardziej się w Polsce rozwijały. I nie było czasu, odkąd Polska oddała cześć Chrystusowi, w którym biskupi byliby bieglejsi nie tylko w pogańskich, ale także w religijnych pismach $^{68}$. Długo by przypominać to wszystko, co wówczas uczynił łaskawie, spokojnie, sprawiedliwie, roztropnie i rozważnie. Co się zaś tyczy pobożności i religii, w tej także sprawie nie chciał być inny od swoich przodków. Albowiem prócz zwykłych modłów, którymi codziennie próbował pozyskać Boską przychylność, nie przepuścił żad-

ważną strategicznie twierdzę. Pod koniec życia monarchy rozpoczęto budowę mostu w Warszawie (1568), którą zakończono po jego śmierci. Dobudowano nowe, renesansowe skrzydło do Zamku Dolnego w Wilnie, zwane Pałacem Nowym (1544), który pełnił funkcję rezydencji wielkoksiążęcej oraz królewskiej. Pracami kierował najpierw Giovanni Cini ze Sieny, a następnie Fryderyk Unsterffe i Job Bretfus. Przebudowano również w renesansowym stylu inne rezydencje królewskie (np. zamki w Niepołomicach, Tykocinie, Knyszynie). Przy Zamku Dolnym w Wilnie król kazał wznieść renesansowy kościół św. św. Anny i Barbary oraz przebudować gotycką katedrę św. Stanisława. Kontynuując dzieło ojca (prace nad przebudową katedry rozpoczął już Zygmunt Stary w 1522 r., ale po kilku latach niedokończoną budowlę strawił pożar), zatrudnił jako architekta Bernardina Zanobiego di Gianotis.

${ }^{68}$ Należy tu przede wszystkim wymienić trzech wysokich urzędników blisko związanych z Zygmuntem Augustem, mecenasów kultury renesansowej: 1) kanclerza Samuela Maciejowskiego (1499-1550), dawnego protektora Stanisława Hozjusza; dzięki poparciu monarchy uzyskał on w 1545 roku najważniejsze biskupstwo krakowskie; 2) podkanclerzego koronnego Filipa Padniewskiego, biskupa przemyskiego (1560-1562) i krakowskiego (1562-1572), doskonałego humanistę (hominem trium linguarum), pisarza politycznego i mówcę podziwianego za elegancję stylu i języka; 3) Piotra Myszkowskiego (ok. 1510-1591), od 1559 roku pełniącego obowiązki wielkiego sekretarza królewskiego, a w latach 1563-1568 podkanclerzego koronnego. Zygmunt August darzył go wielkim zaufaniem, widząc w nim dobrego wykonawcę swoich zamierzeń politycznych. W uznaniu dla jego zasług ofiarował mu wiele beneficjów: prepozyturę gnieźnieńską, łęczycką, płocką, poznańską i dziekanię krakowską. Godność biskupią Myszkowski uzyskał już po śmierci króla. Dzięki opiece i protekcji tych mecenasów do kancelarii królewskiej trafiło wielu utalentowanych humanistów, takich jak: Łukasz Górnicki, Jan Kochanowski, Piotr Rojzjusz, Marcin Kromer, Andrzej Patrycy Nidecki i wielu innych. 
nego dnia bez wysłuchania kapłana sprawującego mszę. Gdy zaś przypadało jakieś święto, uważał, że nie wystarczy wysłuchać tylko mszy, nie dodając kazania, które są u nas głoszone w dane święta we wszystkich kościołach, także w dobrach wiejskich. Ponadto przestrzega się zwyczaju, że przez dwadzieścia, a nawet więcej dni przed Dniem Narodzenia Chrystusa (czas ten nazywają adwentem) codziennie przed świtem śpiewa się mszę dla błogosławionej Dziewicy, podczas której przypomina się żarliwe pragnienie przodków przygotowujących się na [przyjęcie] Chrystusa, z jakim oczekiwali przybycia Odkupiciela w ludzkim ciele. Czyta się [wówczas] takie słowa proroka: „Niebiosa, wysączcie z góry sprawiedliwość i niech obłoki z deszczem ją wyleją!" ${ }^{69}$. [Nasz król] zadbał, by ta msza była codziennie sprawowana bardzo uroczyście przez kantorów, których utrzymywał. Ponadto uważał, że nie wystarczy słuchać śpiewających. Trzeba także swój śpiew do nich dołączyć. Utrzymywał zaś kantorów niemałym kosztem, a na kilka lat przed śmiercią nie wykorzystywał ich do niczego innego prócz spraw Boskich. A jakże gorliwie brał udział we wszystkich obrzędach Kościoła w czasie tego tygodnia, który nazywają świętym, spędzając w świątyni wiele godzin, aby dać przykład poddanym. Wzorem swoich przodków, jak każdy z nich, był pełen czci dla Świętej Stolicy Apostolskiej. Nie było takich uprzejmości czy przejawów czci, których by

${ }^{69}$ Iz 45,8: „Niebiosa, wysączcie z góry sprawiedliwość i niech obłoki z deszczem ją wyleją! Niechajże ziemia się otworzy, niechaj zbawienie wyda owoc i razem wzejdzie sprawiedliwość”. Do słów proroka nawiązuje pieśń śpiewana podczas mszy ku czci Najświętszej Marii Panny wielbionej jako jutrzenka zapowiadająca nadejście słońca. Mszę tę (od pierwszych słów tej pieśni, „rorate caeli desuper”, zwaną roratami) wprowadzono w Polsce w średniowieczu. Odprawiano ją w okresie adwentu, codziennie przed świtem. W wielu polskich katedrach roraty śpiewane były przez specjalne kolegia fundowane przez znakomite osobistości. Wielką sławę zyskały nabożeństwa w kaplicy Najświętszej Marii Panny, wzniesionej na Wawelu przez króla Zygmunta I Starego. Celebrowane były przez powołaną i uposażoną przez tego monarchę, a potem przez jego następcę, kapelę rorantystów. To niewielkie kolegium, w którego skład wchodzili duchowni wyłącznie polskiego pochodzenia, działało w katedrze na Wawelu od 1543 do 1794 roku. 
nie okazał przysłanym przez nią nuncjuszom i legatom ${ }^{70}$. Nieraz usilnie żądano od niego na ważniejszych zgromadzeniach w królestwie, by pozwolił połączyć $\mathrm{z}$ wiarą chrześcijańską herezję augustiańską ${ }^{71}$, to znaczy by pozwolił równocześnie czcić w swoim królestwie Chrystusa i Beliala ${ }^{72}$, lecz nie zdołano tego uzyskać. Mówił, że w kwestii religii nie ma władzy czegokolwiek postanawiać, że mają papieża, mają biskupów, że sam chętnie by się podporządkował ich osądowi w sprawach, które odnoszą się do religii, i uznał ich jurysdykcję. Mówił, że wie, ja-

${ }^{70} \mathrm{~W}$ czasie samodzielnego panowania Zygmunta Augusta jako wysłannik Stolicy Apostolskiej od stycznia do września 1548 roku przebywał w Polsce o. Girolamo Martinengo Cesaresco. Jego pobyt przypadał na okres walki króla o uznanie jego małżeństwa i koronację Barbary Radziwiłłówny. Zgodnie z nakazami papieża Pawła III, chcącego pozyskać przychylność monarchy w sytuacji rozdźwięku i kontrowersji pomiędzy Rzymem a dworem cesarskim, o. Martinengo starał się uspokoić wzburzone umysły szlacheckie i przekonać członków episkopatu do oddawania Barbarze honorów należnych królowym. W 1555 roku papież Juliusz III powołał na stanowisko pierwszego nuncjusza apostolskiego w Polsce Luigiego (Alojzego) Lippomana, który sprawował tę funkcję do roku 1558. Podobnie jak Hozjusz był człowiekiem kontrreformacji. Uważał, że należy się przeciwstawiać reformacji wszelkimi możliwymi środkami. Domagał się od króla między innymi ograniczenia swobód protestantów. Gorliwość, brak elastyczności i niezrozumienie polskich realiów pociągnęły za sobą wiele błędów, które przysporzyły Lippomanowi wrogów oraz osłabiły autorytet Rzymu. Próbował odbudować go Bernardo Bongiovanni, który był nuncjuszem od 1560 do 1563 roku. Trzeźwo oceniając sytuację, działał z taktem i umiarem. Cieszył się dużą sympatią Polaków i poparciem króla. Dwukrotnie nuncjuszem był Giovanni Francesco Commendone (1563-1565, 1572-1573), który przeciwstawiał się planom utworzenia Kościoła narodowego i oporowi szlachty wobec jurysdykcji kościelnej. Doprowadził do przyjęcia przez Zygmunta Augusta na sejmie w Parczewie w 1564 roku uchwał Soboru Trydenckiego oraz wspólnie z Hozjuszem spowodował wydanie edyktu skazującego cudzoziemskich różnowierców na wygnanie z Polski. Nigdy nie zdołał natomiast nakłonić monarchy do wojny z Turcją. Bliższe relacje łączyły króla z Vincenzem dal Portico, przebywającym w Polsce od 1567 roku. Zygmunt August omawiał z nim sprawy swoich fundacji dla kościoła św. Anny i kolegium jezuitów w Wilnie.

${ }^{71}$ To znaczy zapoczątkowaną przez Marcina Lutra, eksmnicha z zakonu augustianów eremitów.

${ }^{72}$ Belial - wcielenie bezprawia, zła; szatan, anioł ciemności, książę piekieł. Dzieci Beliala - warchoły, nicponie, ludzie przewrotni, niegodziwi. 
kie jest jego powołanie, że ma więcej niż potrzeba obowiązków w sprawach państwowych, żeby jeszcze mieszać się do kościelnych i że nigdy tego nie uczyni. Słyszeliśmy również, jak mówił, gdy domagano się od niego czegoś, co uważał za niemożliwe do wykonania bez szkody dla religii, że raczej zrezygnuje z władzy królewskiej i wszelkich godności, niż da posłuch takim żądaniom. "Cóż bowiem - mawiał - za korzyść odniesie człowiek, choćby cały świat zyskał, a na swej duszy szkodę poniósł? Albo co da człowiek w zamian za swoją duszę?"73 Czyż nie są to słowa godne prawdziwie chrześcijańskiego króla? Któż mógłby wątpić, że przynoszą one wielkie szczęście i radość także chórom anielskim? [Są to] słowa, które zawsze powinni mieć na ustach, a jeszcze bardziej w sercu, wszyscy królowie i książęta, ilu ich tylko jest w świecie chrześcijańskim. Zresztą jeśli czegoś mogło mu przypadkiem nie dostawać, to wynikało to raczej z ludzkiej słabości niż z tego, że nie chciał ochoczo uczynić wszystkiego, by zostawić swoim następcom taki stan religii, jaki przejął od swoich przodków. Okazał się do tego bardziej skłonny w swojej woli, niż miał możliwości.

Nad tym, co dzieje się w reszcie świata chrześcijańskiego, nad stanem rzeczy, zwłaszcza tych, które odnoszą się do religii, boleje razem ze mną wielu z nas. Nikt nie zdoła zaprzeczyć, że sytuacja religii jest w królestwie o wiele bardziej znośna. Co się [zaś] tyczy samej osoby króla, każdy może się przekonać, że z całą mocą sprzeciwiał się wszelkiemu rodzajowi sekt, które, [do tego] tak różne, rozdarły jak można zobaczyć - cały świat chrześcijański. Nie dał się nakłonić żadnymi argumentami, by słuchać heretyka głoszącego kazanie ani nie uznał za właściwe brać udział w bluźnierczych raczej niż świętych obrzędach [tych sekt]. Jego odejście z tego życia pokazuje, jak był niewzruszony w wierze katolickiej. Albowiem gdy tylko zrozumiał, że jest już bliska godzina, w której będzie musiał stanąć przed trybunałem Chrystusa i przenieść się do wiecznego domostwa, nie zaniechał żadnej powinności chrześcijańskiego i katolickiego króla względem samego siebie. Na dzień przed śmiercią, wezwawszy księ-

${ }^{73}$ Mt 16,26. 
dza, wyznał wszystkie swoje grzechy, dając świadectwo wielkiego żalu, jaki odczuwał z ich powodu, zgodnie z obyczajem Kościoła katolickiego poprosił, aby udzielił mu rozgrzeszenia, i wkrótce potem w obecności wielu senatorów królestwa, urzędników swojego dworu z nadzwyczajną pokorą przyjął przenajświętsze ciało Chrystusa z rąk biskupa krakowskiego, który był także podkanclerzem koronnym. Następnej nocy został namaszczony świętym olejem przez kapłana, który był jego kaznodzieją ${ }^{74}$. Następnego dnia (przypadał on na nony lipcowe ${ }^{75}$ ) wysłuchał pobożnie liturgii (tak Grecy nazywają mszę) i wkrótce po jej zakończeniu, pokładając całą ufność w miłosierdziu Boga, powierzył mu swojego ducha i odszedł spokojnie i łagodnie. Taki był koniec naszego króla Zygmunta Augusta. Z niego czerpiemy najlepszą nadzieję, że Bóg, który jest dobry, łaskawy i miłosierny, darował mu wszystkie grzechy, którymi nie mógł Go nie obrazić, i uznał godnym korony niebieskiej chwały. Zdaje się, że tak właśnie z nim się stało. Tymczasem jednak dla nas, nie dla niego, spadła korona $\mathrm{z}$ naszej głowy. Nie tylko korona Zygmunta Augusta, lecz także całego rodu jagiellońskiego, który panował nam łaskawie, sprawiedliwie, mądrze i roztropnie przez sto osiemdziesiąt cztery lata. Cóż więc pozostaje czynić nam, osieroconym nie tyle przez króla i pana (nie można w nim było bowiem dostrzec żadnej pychy, żadnego królewskiego samowładztwa), ile przez ojca? Cóż innego nam pozostaje, jak [tylko] zwrócić nasze oczy i serca do wspólnego dla wszystkich Króla i Ojca, odczuwając słuszny żal z powodu grzechów,

${ }^{74} \mathrm{~W}$ ostatnich chwilach życia Zygmuntowi Augustowi towarzyszył biskup krakowski Franciszek Krasiński (1522-1577), piastujący tę godność od czerwca 1572 roku. Związany był z królem od 1560 roku, gdy został jego sekretarzem, a od roku 1568/1569 do 1572 sprawował urząd podkanclerzego koronnego. Przy monarsze byli także marszałek nadworny litewski Michał Krzysztof Radziwiłł oraz referendarz koronny Stanisław Sędziwój Czarnkowski, który czytał konającemu Pismo Święte. Nadwornym kaznodzieją był zaś profesor Akademii Krakowskiej Marcin Nerwicjusz, który funkcję tę pełnił od marca 1570 roku.

${ }^{75}$ Nony lipcowe -7 lipca. W kalendarzu rzymskim nony to 5. lub 7. dzień miesiąca. 
którymi wzbudziliśmy Jego straszny gniew, i odmieniając życie na lepsze, błagać Jego miłosierdzia. Najpierw, aby zechciał być łaskawy dla duszy naszego zmarłego króla, następnie by zatroszczył się dla nas o następcę, który zdołałby ukoić wielką tęsknotę i smutek, jakie pozostawił po sobie zmarły król. Z tego też powodu szukajmy zakończenia mowy w tym samym ustępie z proroka, z którego wzięliśmy początek $^{76}$. Ponieważ wszystko na tym świecie jest chwiejne i nietrwałe i nie można zobaczyć w nim nic stałego, niewzruszonego, nic niezmiennego, długotrwałego, ponieważ wszystko obraca się i toczy niczym koło, nasze dni [są] jak opar i cień, widoczne [tylko] przez moment, [a] za chwilę się rozproszą, znikną niczym dym ${ }^{77}$. „Lecz Ty, o Panie, Ty trwasz na wieki. Twój tron poprzez pokolenia. Czemu chcesz o nas zapomnieć na zawsze, po wszystkie dni opuścić? Na-

76 Prorok Jeremiasz w wersach poprzedzających (Jr 13,15-16) przywoływaną na początku kazania myśl nawołuje lud Izraela do odrzucenia pychy, pokornego oddania się i zawierzenia Bogu: „Słuchajcie i uważajcie bacznie; nie unoście się pychą, bo Jahwe przemówił. Oddajcie chwałę Jahwe, Bogu naszemu, zanim ciemności nastaną i zanim potykać się będą wasze nogi w mrocznych górach”.

77 Hozjusz nawiązuje do Księgi Mądrości 2,1-5: „Nasze życie jest krótkie i minie! [...] Urodziliśmy się niespodzianie i potem będziemy, jakby nas nigdy nie było. [...] Przeminie życie nasze jakby ślad obłoku i rozwieje się jak mgła ścigana promieniami słońca i żarem jego przybita. Czas nasz jak cień przemija, śmierć nasza nie zna odwrotu”. Zob. też Księgę Psalmów, na przykład Ps 144(143),4: „Człowiek jest podobny do tchnienia wiatru, dni jego jak cień mijają”, oraz List św. Jakuba 4,14: „Bo czymże jest życie nasze? Parą jesteście, co się ukazuje na krótko, a potem znika”. Podobne myśli odnajdujemy u Seneki. W Pocieszeniu do Marcji XXI 1 filozof mówi na przykład: „Wszystko, co ludzkie, jest krótkotrwale i marne” („omnia humana brevia et caduca sunt”), L.A. Seneka, Pocieszenie do Marcji, w: idem, Dialogi, s. 392; tekst łaciński za: idem, Opera, s. 132. W Listach moralnych do Lucyliusza XVI 99 z kolei czytamy: „Wszystko jest ulotne, zwodnicze i bardziej niestałe niźli sam czas. Wszystko się obraca i na rozkaz losu przemienia się w coś przeciwnego, a przy takiej zmienności spraw ludzkich pewna jest dla każdego jedynie śmierć” („Nihil non lubrium et fallax et omni tempestate mobilius, iactantur cuncta et in contrarium transeunt iubente fortuna, et in tanta volutatione rerum humanarum nihil cuiquam nisi mors certum est"), idem, Listy moralne do Lucyliusza, s. 519; tekst oryginału za: idem, Ad Lucilium epistulae morales, t. 2, s. 412 . 
wróć nas, Panie, do Ciebie wrócimy. Dni nasze zamień na dawne!"78. Podobało Ci się, Panie, odmienić nasze dni, odmień je [teraz] tak jak na początku. Spodobało się Tobie przenieść polską koronę na inny ród? Zaiste, nie sprzeciwiamy się Twojej woli. Pokornie błagamy Cię jedynie o to, abyś odnowił wszystko tak jak na początku. Chcesz dać nam nowego króla? Daj takiego, jacy byli Jagiellonowie, zwłaszcza dwaj Zygmuntowie, ojciec i syn. Oby ten panował nam równie łaskawie, łagodnie, mądrze, sprawiedliwie, spokojnie i rozważnie. Gdy będzie dzierżył ster królestwa, oby sytuacja religii była taka sama, jak za ojca [króla] Zygmunta Augusta. Oby panował taki sam spokój, jaki był za rządów ich obu. Niechaj tak nami włada, żebyśmy w tym życiu opływali w dobra doczesne, a gdy przeniesiemy się do lepszego żywota - w dobra wieczne i abyśmy Twoje imię nieprzerwanie chwalili i wielbili na wieki wieków. Amen.

Przełożyła i komentarzem opatrzyła Justyna Zaborowska-Musiał 